\title{
Flood hazard assessment and mapping in semi-arid piedmont areas: a case study in Beni Mellal, Morocco
}

\author{
Gabriela Werren $^{1} \cdot$ Emmanuel Reynard $^{1} \cdot$ Stuart N. Lane $^{1}$ • \\ Daniela Balin ${ }^{1}$
}

Received: 22 July 2014/ Accepted: 16 November 2015/Published online: 24 November 2015

(C) The Author(s) 2015. This article is published with open access at Springerlink.com

\begin{abstract}
Flood hazard assessment and mapping is challenging in semi-arid ungauged basins because of the lack of data, the rapid runoff response, climatic variability, and the difficulties of modelling hydraulic processes, such as on piedmont alluvial fans. This study combines hydrological and hydraulic modelling with hydro-geomorphic knowledge gathered during post-flood campaigns in order to determine realistic flood hazard scenarios for a piedmont urban area in Morocco. Partial calibration of the hydrological and hydraulic models is performed using field-estimated peak discharge values and mapped flood extents for known flood events. The calibrated models are then applied to lower frequency-higher magnitude flood scenarios. Finally, a flood hazard map is designed using the Swiss hazard assessment and mapping procedures.
\end{abstract}

Keywords Semi-arid catchments · Hydro-geomorphic mapping · Post-flood investigations · Hydrological-hydraulic modelling · Flood hazard assessment · Flood hazard mapping

\section{Introduction}

Climatic scenarios suggest that Mediterranean climates are tending towards increased aridity and higher inter- and intra-annual rainfall variability, resulting in more frequent extreme events (Giorgi and Lionello 2008; IPCC 2012). Moreover, risks related to flooding have been increased in Mediterranean countries, such as Morocco, because of rapid urban and economic development in flood-prone areas, increasing people's exposure to flood hazards (UNDP 2006). In Morocco, recent urbanization on alluvial fans at the margins of mountainous regions is particularly affected by flash floods resulting from topographically

Gabriela Werren

gabrielawerren@yahoo.com

$1 \quad$ University of Lausanne, Lausanne, Switzerland 
induced rainfall events (UNDP 2006; Saïdi et al. 2010). Actions are required both to avoid urban development in flood-prone areas and to adapt existing and planned development to future climate change. One way of doing this is through better assessment of flood hazard.

Hydrological and hydraulic models are essential when assessing flood hazard for planning-relevant scenarios. However, flood hazard assessment may be challenging in semi-arid piedmont areas requiring the use of methodologies and techniques uncommon to most hazard assessment studies (Vincent et al. 2004; House 2005). The main difficulty for modelling arises from the lack of rainfall and discharge data (Gaume et al. 2009), as many mountainous catchments are ungauged. Moreover, semi-arid catchments commonly have a very rapid hydrological response (Hooke 2006; Latron et al. 2009) reflected in the occurrence of flash-flood events that are difficult to monitor with conventional gauging stations (Borga et al. 2010). Finally, flood hazard scenarios that are relevant for land use management and planning relate to flood events with a relatively high return period (e.g. 20 to 100 years). Predicting such infrequent events in conditions of scarce data and high rainfall variability can result in high model uncertainty.

Despite the need for hydrological modelling, two particular challenges arise. First, there is a difficulty in extrapolating methods developed in temperate conditions to semi-arid environments (Pilgrim et al. 1988). Certain lithologies, notably those that are calcareous and that are characteristic of some Mediterranean catchments, are often associated with shallow soils (Yaalon 1997) that can limit the use of hydrological models conceived for deep soil conditions (e.g. Liu et al. 2011). Second, more specifically, in piedmont zones such as alluvial fans and aprons, flood hazard scenarios are required to represent complex, unconfined flows and highly uncertain flow paths (Pelletier et al. 2005).

Given these difficulties, assessment of flood hazard in ungauged catchments requires the use of alternative data sources such as remotely sensed data and field-collected hydrogeomorphic flood evidence. Moreover, monitoring and modelling of more frequent flood events may provide useful knowledge on catchment behaviour that can be transferred to higher return period floods. Thorough field knowledge can compensate the uncertainties related to data scarcity and thus permits more realistic flood prediction.

Satellite and radar-borne rainfall data are increasingly used in regions where gauging networks are insufficient (Hong et al. 2007; Nikolopoulos et al. 2010). Remotely sensed data may provide spatially distributed rainfall estimates for often inaccessible catchment areas (Nikolopoulos et al. 2010) that can prove more effective in capturing the spatial and temporal variability in rainfall than point gauges. Rainfall data obtained from airborne sources need to be implemented in a rainfall-runoff model in order to simulate a given flood and assess the hazard associated with it. At this stage, knowledge about catchment properties, and hence possible hydrological behaviour, and the choice of an appropriate rainfall-runoff relationship are essential in order to realistically model the flood event.

When no discharge data are available for model calibration, alternative flood hydrograph estimates are needed. Post-flood investigation campaigns for hydro-geomorphic data collection and flood timing investigation may provide valuable data that can be used for reconstructing flood hydrographs (Gaume and Borga 2008; Borga et al. 2010). Post-flood investigations can provide information about (a) maximum flood discharge, (b) flood timing, and (c) sediment transfer processes (Gaume and Borga 2008). Several studies conducted in areas with a lack of measured data have combined hydro-geomorphic mapping and hydraulic flood discharge estimates in order to assess flood hazard (e.g. Gaume et al. 2004; Chave and Ballais 2006; Fernandez-Lavado et al. 2007). High water marks as well as specific monitored cross sections provide the basis for a hydraulic estimation of the maximum flood discharge (Vincent et al. 2004). 
Likewise, post-flood mapping of maximum inundation extent using high water marks can provide calibration means for hydraulic flood modelling when measured discharge or stage data are missing (Tayefi et al. 2007). Hydro-geomorphic mapping of past flood markers may provide information on system dynamics (erosional-depositional patterns, flow intensity) and thus enhance hydraulic modelling of complex flow patterns specific to alluvial fans (Vincent et al. 2004). Mapping infrastructure that contributes to flood hazard (e.g. undersized culverts that trigger flood overspills) may also better inform the modelling process.

This study's aim is to assess and to map flood hazard in the semi-arid piedmont area of Beni Mellal, in Morocco, drained by four small Mediterranean streams. In this context, this research combines the use of the TRMM (Tropical Rain Measuring Mission) satellite rainfall estimates (Huffman et al. 2009), hydro-geomorphic mapping, and post-flood campaigns to model known flood events. The simulated flood hydrographs are used as an input for assessing flood hazard in terms of flood extent and magnitude within the adjacent urbanized piedmont area (Fig. 1). Field knowledge derived from hydro-geomorphic mapping campaigns is integrated into the hydrological and hydraulic models. The enhanced models are used to predict lower frequency-higher magnitude flood events necessary to the process of flood hazard assessment and mapping as a risk mitigation strategy. Finally, a flood hazard map is designed, following the Swiss guidelines for hazard assessment and mapping.

Fig. 1 This study's approach to flood hazard assessment in Beni Mellal, Morocco

\section{known} event

Rain: TRMM hypothetical

event

Rain: IDF curve

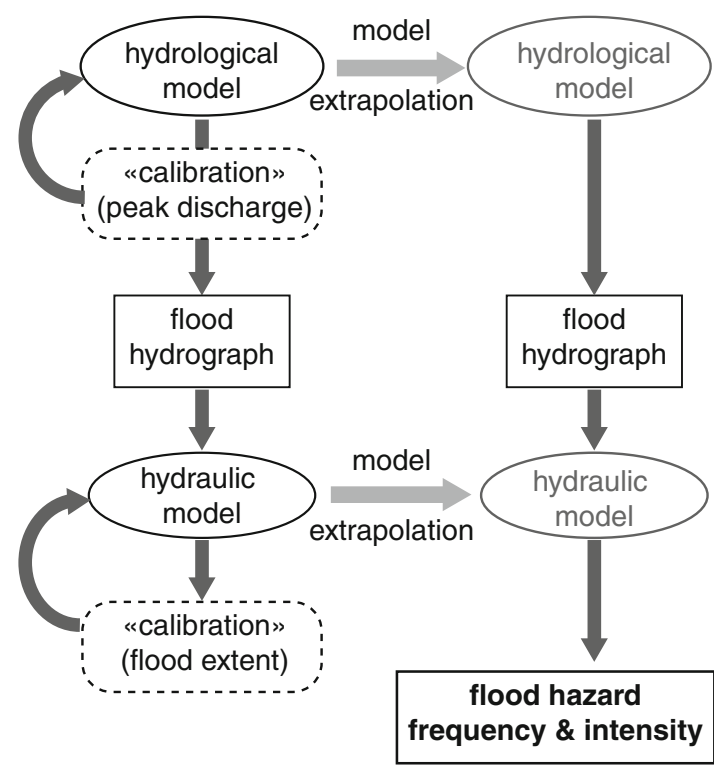




\section{Case study: Beni Mellal, Morocco}

Beni Mellal is the capital city of the Tadla-Azilal region in Morocco and is set on the northern Atlas piedmont, at the outlet of four small-scale semi-arid catchments (Fig. 2) that seasonally trigger short and intense flash floods. These catchments are, from E to W: Sabek $\left(20.8 \mathrm{~km}^{2}\right)$, Aïn el Ghazi $\left(15.8 \mathrm{~km}^{2}\right)$, Handak $\left(29.7 \mathrm{~km}^{2}\right)$, and Kikou $\left(54 \mathrm{~km}^{2}\right)$.

The catchments are located predominantly on Early Jurassic limestones, except for the southern Tasmit ridge, which is formed of marls. The four catchments present typical Mediterranean oak forests and secondary matorral formations (degraded soils and vegetation) at different degrees of degradation. On the marls, badland surfaces have developed where the vegetation cover is depleted. On limestones, the soils are often shallow and skeletal, especially on slopes. A relatively well-developed karst regulates the catchments' hydrology during the dry season, providing irrigation water at the piedmont base through several karstic springs (Bouchaou 1997; El Khalki and Hafid 2002). During the wet season, often marked by convective storms, the shallow soils and sparse vegetation most likely induce Hortonian flows as the infiltration capacity is rapidly exceeded, triggering overland flow (Pilgrim et al. 1988; Osterkampl and Friedman 2000). Due to the onset of rapid runoff, hydrographs are likely to be steep, specific of flash-flood events (Pilgrim et al. 1988). The streams that drain the catchments terminate on a series of large gently sloping fossil alluvial fans. At this point, floodwaters develop in sheet floods that threaten the urban perimeter of Beni Mellal.

Beni Mellal is an example of relatively recent and uncontrolled urban development in Morocco (El Khalki and Benyoucef 2005; El Khalki et al. 2005). The occurrence of a long drought period since 1970 has caused a major rural depopulation from the mountainous areas towards their economically attractive urban outskirts (El Khalki and Benyoucef 2005).

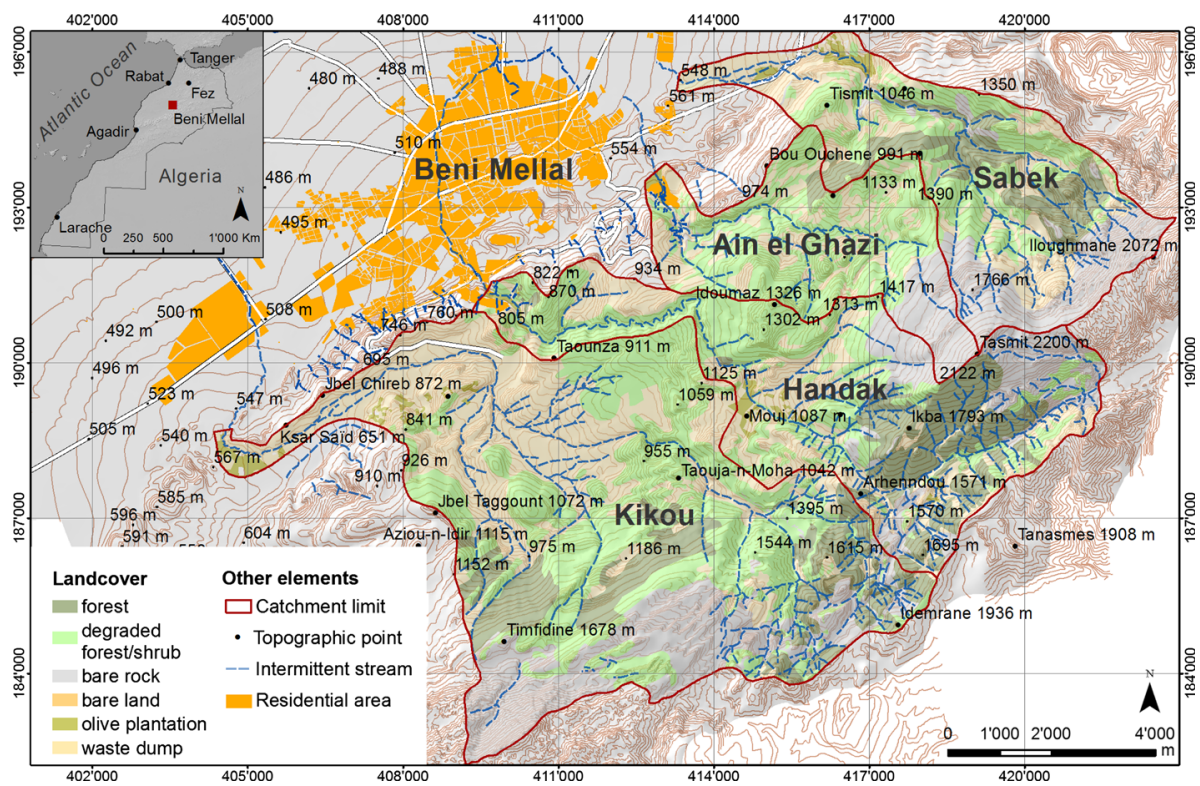

Fig. 2 Beni Mellal, located at the outlet of four small semi-arid catchments. From E to W: Sabek, Aïn el Ghazi, Handak, and Kikou 
Meanwhile, the drought period also triggered important land use changes in the upper catchments such as increased deforestation, cropland abandonment, and deterioration of slope terraces, with possible consequences for catchment hydrological response. There was a marked change in precipitation characteristics since 1995, with much greater interannual variability than had been the case (Fig. 3). Significant urbanization coupled to unregulated and low-quality building in hazard-prone areas has increased the exposure of people and infrastructures to flood hazards, requiring risk mitigation actions to be undertaken (El Khalki et al. 2005; UNDP 2006). The local authorities have adopted a series of structural mitigation measures, including the construction of flood reduction dams at the catchment outlets and recalibration of the streambed within the urbanized area (ABHOER 2004; ADI 2004).

As part of a hazard assessment and mapping project (Werren 2013), the assessment of flood hazard was required. In the absence of precipitation and discharge data, a thorough understanding of the catchment hydrological behaviour was needed. Mapping of hydrogeomorphic elements and infrastructure involved in flood development was undertaken. During the study period, two flood events were considered and studied through post-flood investigations in Morocco in 2010. The 14 February 2010 flood event occurred during a relatively wet period related to winter low-pressure zones accentuated by High Atlas orographic forcing. The 11 October 2010 event occurred in an early autumn situation marked by convective activity.

\section{Hydro-geomorphic mapping and post-flood campaigns}

Thorough knowledge of the hydro-geomorphological system from geomorphic mapping campaigns may improve decision-making within the flood modelling process. Such campaigns may allow: (1) identification of the area prone to flood hazard; (2) development of important knowledge regarding catchment properties and flood dynamics; and (3) provide the means of model verification in ungauged catchments. Two field campaigns

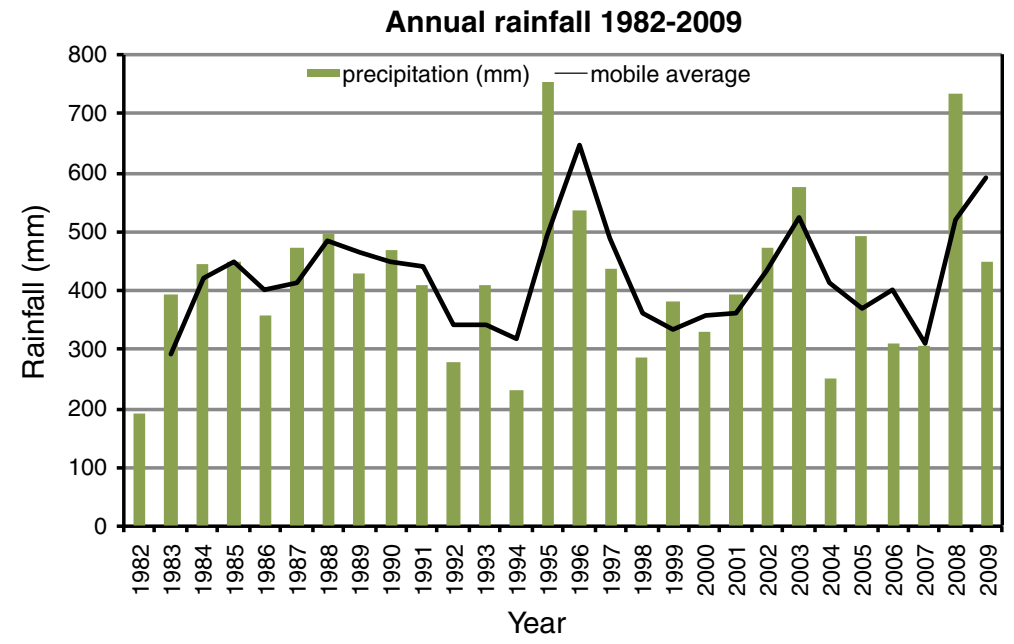

Fig. 3 Annual precipitation in Beni Mellal (1982-2009). Mobile average period: 2 years. Source: ABHOER 
were carried out during the spring and autumn 2010. The objective was to obtain a map of hydro-geomorphological information to help hazard assessment.

\subsection{Hydro-geomorphic mapping}

The mapping campaign focussed on hydro-geomorphic elements relevant for the development of floods (Reynard et al. 2013). Erosional and depositional forms (active and inherited) were mapped along the four streams and on the fan surface. For instance, according to the NRC method for flood hazard mapping on alluvial fans (NRC 1996), and several studies carried out on arid alluvial fans, active fan areas (containing recent deposits) are more likely to be flooded (House 2005; House et al. 2007). At the same time, palaeochannels on fans may guide floodwaters into inactive fan areas. Using such information may help inform the modelling process. The maximum flood extent for the two reference events that occurred in February and October 2010 was likewise delimited in the field. Flood extent data provided means for verifying the results of hydraulic modelling undertaken in the subsequent hazard assessment phase. Finally, infrastructure that interacted with the flooding process during these events was also mapped (undersized bridges and culverts, road embankments with an obstructing effect). These data were collected in order to support the hydraulic modelling process by identifying infrastructure-related overflow points.

\subsection{Post-flood discharge estimates}

Discharge estimates were undertaken mainly to support the hydrological modelling process. High water marks in reference cross sections, flow velocity estimates using splash marks on flow obstacles, and eyewitnesses' testimonies on the flood timing were collected following both events. We surveyed cross sections located at the outlet of the four catchments, on channelized reaches situated upstream of the fan hydrological apex where flow turned into sheet flood.

Hydraulic estimation of the peak discharge was undertaken using field-collected elements. Field-based hydraulic calculations are subject to a series of simplifying assumptions, especially when estimating peak discharge for flash floods. In the absence of better data, an extremely simple discharge reconstruction was undertaken using the simplification of one-dimensional, steady flow. The peak discharge was approximated in the following way. The peak discharge $\left(Q_{\mathrm{p}}\right)$ is defined as:

$$
Q_{\mathrm{p}}=A_{\mathrm{p}} V_{\mathrm{p}}
$$

where: $Q_{\mathrm{p}}=$ discharge at the flood peak $\left(\mathrm{m}^{3} / \mathrm{s}\right) ; A_{\mathrm{p}}=$ the cross section at the flood peak $\left(\mathrm{m}^{2}\right)$; and $V_{\mathrm{p}}=$ the section-averaged flood peak velocity $(\mathrm{m} / \mathrm{s})$. By choosing relatively stable cross sections that contained all of the flood water, it was possible to estimate $A_{\mathrm{p}}$ with reasonable reliability using the field mapping. Cross section stability is certainly subject to caution due to bed scour and back-fill effects that could occur during the flood event (Vincent et al. 2004). An estimate of flood peak velocity was also required. This applied the Manning relationship:

$$
V_{\mathrm{p}}=n^{-1} R_{\mathrm{h}}^{2 / 3} * S^{1 / 2}
$$

where: $n=$ Manning roughness coefficient; $A=$ wetted cross section area $\left(\mathrm{m}^{2}\right)$; $R_{\mathrm{h}}=$ hydraulic radius; $S=$ water surface slope. The hydraulic radius $R_{\mathrm{h}}$ is given by the ratio of the wetted area $A\left(\mathrm{~m}^{2}\right)$ and the wetted perimeter $H<0.5(\mathrm{~m})$ in a cross section. 
High water marks were used to estimate the wetted cross section and perimeter at the reference cross sections. The roughness coefficient and the relative water surface slope were estimated in the field. Information about flow velocity nearby surveyed sections was obtained from splash marks on flow obstacles such as bridge piers, according to a method described by Gaume and Borga (2008).

Flood timing as estimated from comments from eyewitnesses may enhance understanding of the studied flood and provide useful insight in shaping the flood hydrograph (Gaume et al. 2004; Fernandez-Lavado et al. 2007; Gaume and Borga 2008). Where possible, information on the flood timing was collected from local people.

\section{Hydrological modelling}

Knowledge of the hydrological behaviour within the studied catchments was built by simulating known flood events. The model so obtained was used to simulate flood scenarios for given reference events. In the absence of measured data, TRMM rainfall satellite estimates were used as an input for the hydrological modelling. After the storm design step, simple conceptual hydrological modelling was undertaken using the transfer function concept through the Snyder hydrograph unit model. The effective rainfall was computed using as production function three different infiltration models. These models were tested in order to optimally represent the catchment hydrological behaviour. Calibration of the model was partially undertaken using peak discharge values estimated in the field.

\subsection{Rainfall data and spatial modelling}

The TRMM 3B42 rainfall product has provided, since 1998, multi-satellite rainfall estimates with a spatial-temporal resolution of $0.25^{\circ}$ and $3 \mathrm{~h}$, in grids with quasi-global coverage (Hong et al. 2007; Huffman et al. 2009). This dataset is freely available on the NASA webpage at trmm.gsfc.nasa.gov. Several studies have demonstrated the utility of TRMM datasets in estimating rainfall for hydrological modelling of medium-sized and large catchments (e.g. Hong et al. 2007; Su et al. 2008; Nikolopoulos et al. 2013; Yong et al. 2012). Less testing has been undertaken in smaller catchments (less than $100 \mathrm{~km}^{2}$ ). Nikolopoulos et al. (2010) showed that the error propagation from satellite rainfall estimates to a hydrological model is dependent on the catchment scale: in small-scale applications, product resolution becomes a critical issue. Even though the spatial resolution is relatively coarse compared to the scale of the studied catchments, this open-source dataset provided the most precise available rainfall representation in terms of temporal resolution. Rainfall estimates for the two 2010 events were treated as point rain gauges located at the centre of the grid cells covering the area of the four catchments in this study (Fig. 4).

A meteorological model was then established using the US Corps of Engineers software HEC-HMS (http://www.hec.usace.army.mil/software/hec-hms/). The meteorological model undertakes rainfall data interpolation and temporal disaggregation. For given nodes on the catchments surface, average precipitation was calculated using the inverse-distancesquared scheme (USACE 2000). This method assumes that precipitation is evenly distributed over a given area (catchment or sub-basin) and a given time period. A time step of 20 min was chosen to discretize the 3-h rainfall estimates (Fig. 5). 


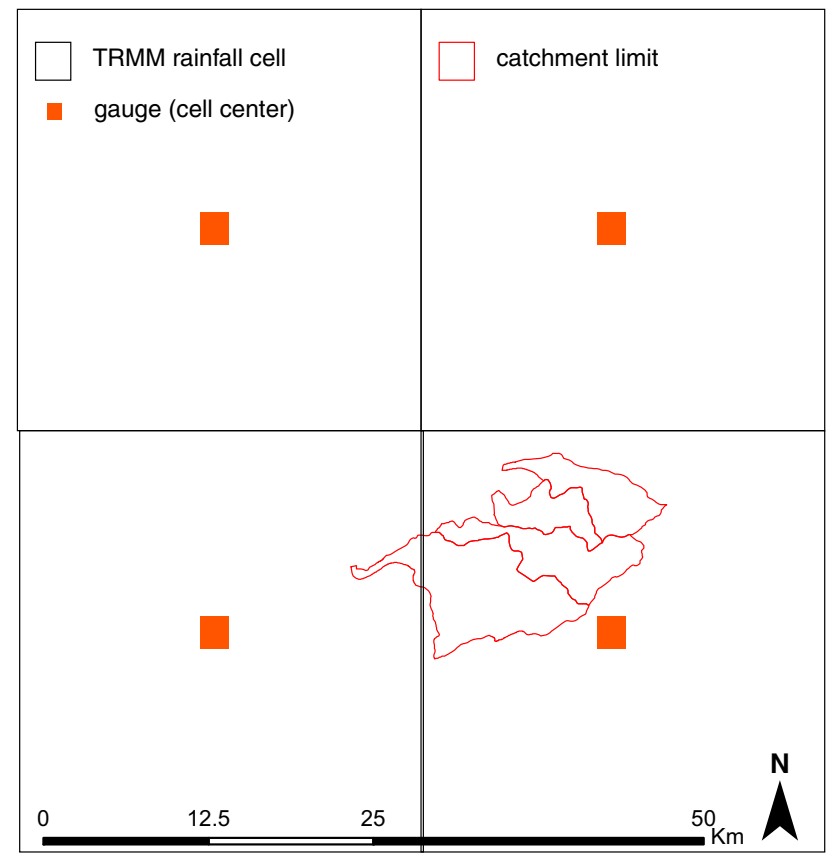

Fig. 4 TRMM rainfall cells covering the study area. Data retrieved from the TRMM platform at trmm.gsfc.nasa.gov

\subsection{Preparation of topographic data}

Digital elevation models were interpolated for each catchment using contour lines from the 1:50,000 topographic map at a 10-m resolution. Streams were burned in during the process using the Topo to Raster tool in ArcMap. Catchment pre-processing for use in HEC-HMS was undertaken using the ArcHydro Tools and HEC-GeoHMS extensions in ESRI ArcMap. Land use data were digitized from a 2009 GeoEye image provided by Google Maps. As no soil map was available for the study catchments, soil characteristics were deduced from alternative datasets (lithology, slope, vegetation cover) using a functional factorial approach as defined by Jenny (1941). This approach states that pedogenetic factors can predict soil classes or specific soil characteristics on the basis of environmental correlation (McKenzie and Ryan 1999; McBratney et al. 2003). Soil characteristics were predicted using a decision tree containing three criteria: parent material $(P)$, slope $(\mathrm{Sl})$, and vegetation type $(O)$ (Fig. 6). Soils were classified according to their expected hydrological characteristics using the National Resources Conservation Service (NRCS) runoff potential groups (NRCS 2007). Catchment characteristics were considered globally in a lumped model in agreement with the relatively small basin area and the poor rainfall input data resolution.

\subsection{Effective rainfall production and rainfall-runoff transfer functions}

In the studied area, hydrological processes are most likely to involve an infiltration excess mechanism. Thus, infiltration is the main control of direct runoff generation. In a lumped, 

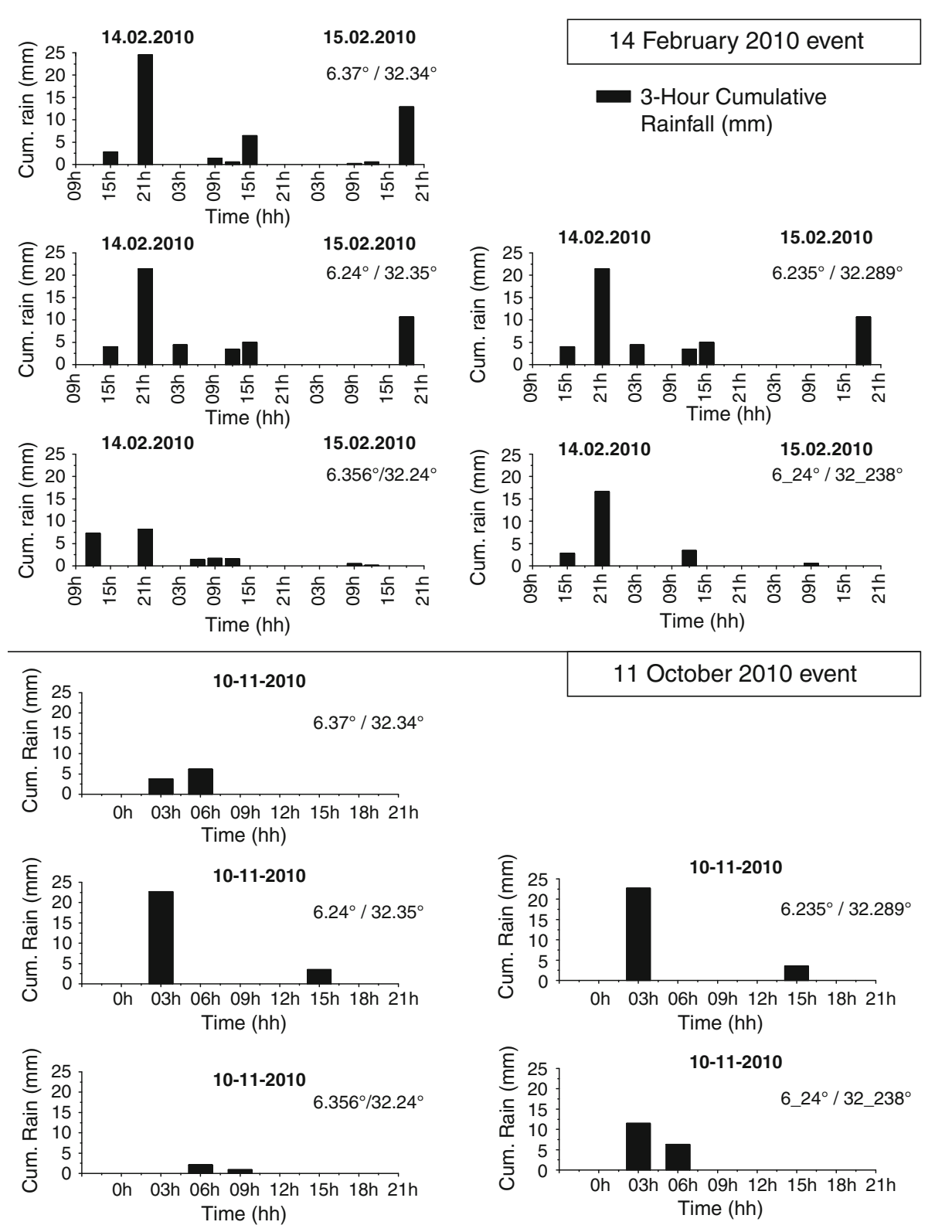

Fig. 5 Rainfall estimates for the events of 14 February and 11 October 2010. Data retrieved from the TRMM platform at trmm.gsfc.nasa.gov

event-based approach, three infiltration models available within the HEC-HMS modelling system were tested: the Green-Ampt physically based model (Green and Ampt 1911), the SCS Curve Number methodology, and the initial and constant infiltration model (USACE 2000), in order to select the model most appropriate to the catchments' semi-arid 


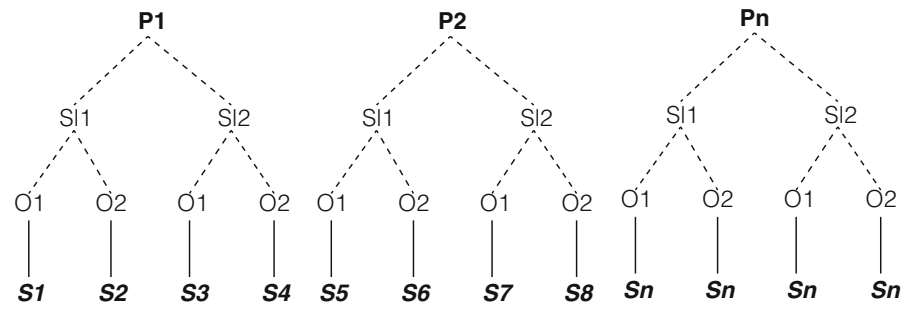

Fig. 6 Decision tree for predicting soil characteristics. $P$ parent material, $S l$ slope, $O$ organismus (here vegetation), $S$ resulting soil type

conditions. The rainfall-runoff relationship was expressed using the Snyder unit hydrograph method, a parsimonious model that relates the rainfall duration to the catchment lag (Snyder 1938; USACE 2000).

\subsection{Calibration using post-flood investigations}

In ungauged catchments where classical calibration approaches are impossible, geomorphic evidence can provide the means for partial verification of the used hydrological model. Post-flood campaigns provided flood peak discharge estimates for the two events, even if these estimates remain uncertain given the methodology used and described above. These estimates were first compared with the modelled peak hydrographs (Fig. 7) in order to choose the best-fitting infiltration method for the given catchments. Then, the data were used to partially calibrate the model output in terms of peak discharge. Flood timing was also verified based on local people's testimonies.

\subsection{Extrapolation to hypothetical events}

The model tested on known events was then applied to simulate lower frequency-higher intensity flood events. We used rectangular design storms with duration $=1 \mathrm{~T}_{\mathrm{c}}$ (catchment time of concentration) derived from IFD (intensity-frequency-duration) curves calculated at the Beni Mellal meteorological station. We simulated floods for the 20-, 50-, and 100 -year rainfall events. The model accounted for the role of existing or planned flood reduction dams (according to ADI 2004).

\subsection{Results}

The comparison of flood hydrographs resulting from the three production models and field estimations suggests that the initial and constant loss method could best predict flood hydrographs in terms of peak discharge (Fig. 7). The Green-Ampt model predicted lower runoff volumes and peak discharges. For all four catchments, the SCS-CN infiltration model significantly underestimated flood peak and volume. A possible explanation might be related to the event intensity and short duration, correlated to the SCS assumption that infiltration rate depends on rainfall rate (Smith et al. 1978; Hjelmfelt 1980). The TRMM rainfall estimates 3 -h resolution, and this is probably not sufficiently fine for these short and intense storms, such that the infiltration rate estimated by the SCS-CN method was too high. Thus, the SCS-CN method was not further considered in this study. 

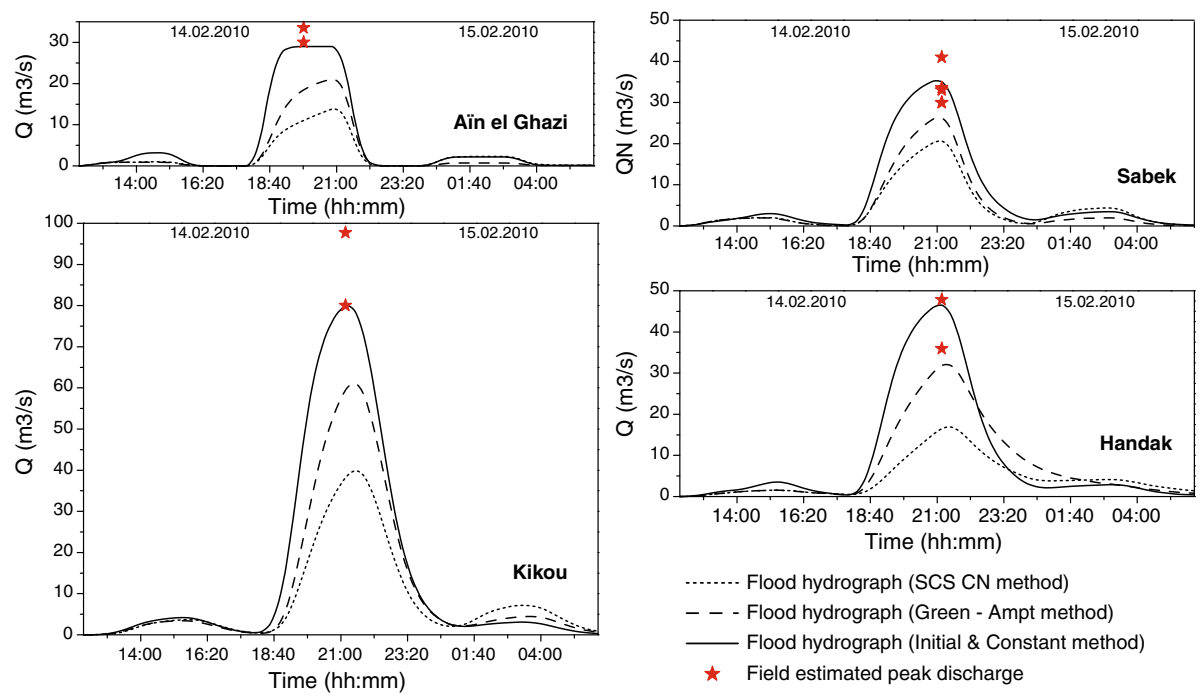

Fig. 7 Comparison of output flood hydrographs for the three tested methods and field-collected peak discharge estimates. Example of the 14 February 2010 event. The peak discharge estimates for Handak catchment were collected upstream of the flood reduction dam

A one-factor-at-the-time (OFAT) sensitivity analysis (Morris 1991) was performed on the initial and constant loss and Green-Ampt method parameters. The analysis showed that the Green-Ampt model could produce better results in terms of the flood hydrograph peak and volume, provided that its most sensitive parameter, i.e. the saturated conductivity, was assigned very small values (10\% of the expected value for each soil type, Fig. 8). The Green-Ampt method models soil as an infinite, homogeneous column where the limit between wet and dry soil is marked by a sharp wetting front. With shallow soils, such as the ones in the studied catchments, the model may fail to predict realistic flood hydrographs, unless saturated conductivity is assigned small values. This finding is corroborated by a study by Liu et al. (2011) that assessed the Green-Ampt model's applicability in shallow soil conditions and proposed lowering the saturated conductivity parameter values for better prediction.

Sensitivity analysis showed that the initial and constant loss method parameters were less sensitive (Fig. 8). The method was therefore considered as more appropriate for the studied catchments (Werren 2013). Sensitivity analysis was equally used to calibrate the model for the two known events (Fig. 9).

Despite the uncertainty related to rainfall data, model parameters and calibration methodology (Werren 2013), no uncertainty quantification was possible with such scarce calibration data. Nevertheless, peak discharge value ranges based on variation in field estimates rather than unique validation criteria were used (Fig. 10).

The obtained flood hydrographs display steep curves reflecting the flash-flood behaviour of the studied catchments (Fig. 9). The Aïn el Ghazi hydrograph is flat-topped: we suggest that this situation arises as the Snyder unit hydrograph convolution might have been hindered by a very short time of concentration $(50 \mathrm{~min})$ and the 3-h rainfall structure of TRMM. Finer rainfall estimates would be necessary for this small-scale catchment. The 

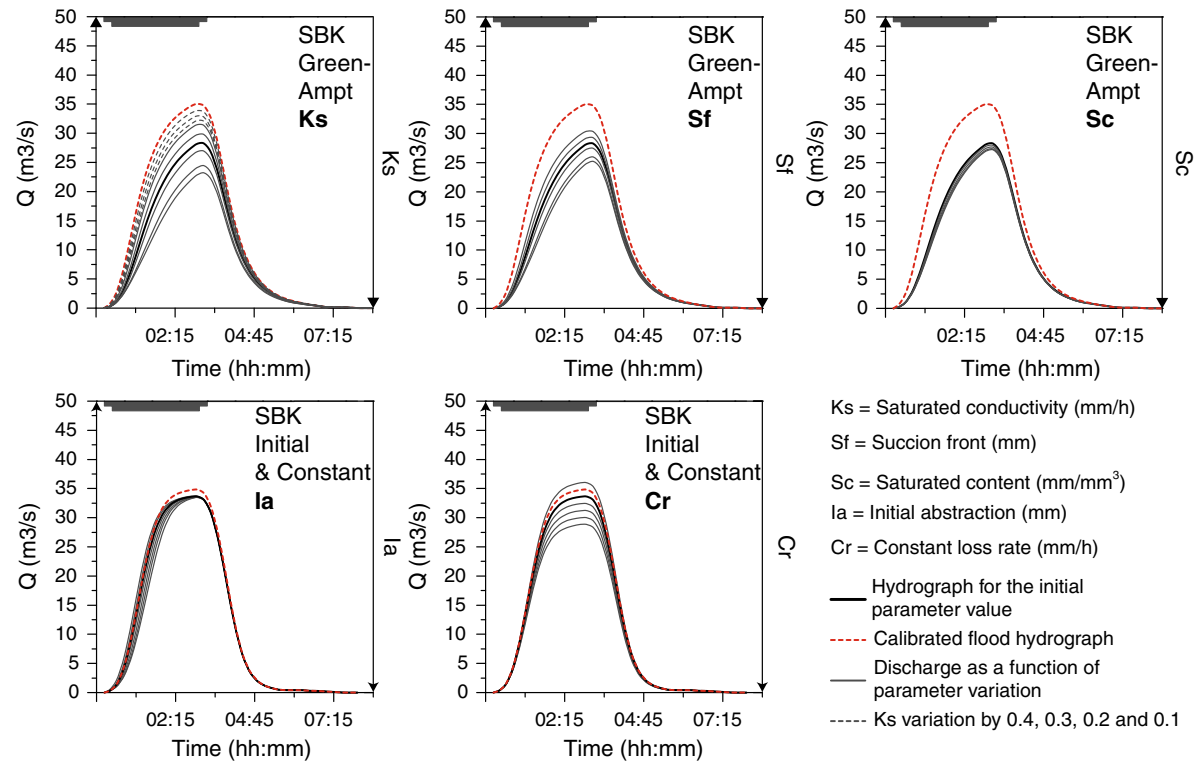

$\mathrm{Ks}=$ Saturated conductivity $(\mathrm{mm} / \mathrm{h})$ $\mathrm{Sf}=$ Succion front $(\mathrm{mm})$

$\mathrm{Sc}=$ Saturated content $\left(\mathrm{mm} / \mathrm{mm}^{3}\right)$ la $=$ Initial abstraction $(\mathrm{mm})$

○ $\mathrm{Cr}=$ Constant loss rate $(\mathrm{mm} / \mathrm{h})$

Hydrograph for the initial parameter value

----- Calibrated flood hydrograph Discharge as a function of - parameter variation

Ks variation by $0.4,0.3,0.2$ and 0.1

Fig. 8 OFAT sensitivity analysis for the Green-Ampt and initial and constant loss model parameters. Example of the Sabek catchment during the 11 October event. Flood hydrographs were obtained by multiplying the initial parameters by 0.5 . $0.75,1.25,1.5$, and 2 . Ks was additionally multiplied by $0.4,0.3$, 0.2 , and 0.1 . From Werren (2013)

flood control role of the dam set at the Handak outlet was accounted for, using the elevation-storage rating function provided by HEC-HMS (USACE 2000).

The final output of the hydrological modelling step consists of flood hydrographs for reference hypothetical events necessary to the hazard assessment procedure. The results suggest that the planned or existing flood reduction dams have little flood control effects for larger events and catchments. Moreover, by producing steeper flood hydrographs these structures seem to induce a flash-flood character to the simulated events (Fig. 11).

\section{Hydraulic modelling}

According to the approach outlined in Sect. 2 (Fig. 1), one known flood event (11 October 2011) was considered as providing a realistic hydraulic model for extrapolation to floods associated with 20-, 50-, and 100-year rainfall events.

Initially, the open-source, one-dimensional HEC-RAS steady flow model (USACE 2010) was tested as it responded to cost-effectiveness criteria related to this project (Werren 2013). However, it failed to represent flow processes specific to the alluvial fan morphology of the Beni Mellal study site (Werren 2013). 2D models, as compared to 1D models (Fig. 12), are thought to deliver better process representation of floods occurring on areas of complex topography such as alluvial plains and fans (Bates and De Roo 2000; Pelletier et al. 2005; Tayefi et al. 2007). Thus, the two-dimensional, unsteady flow TUFLOW model (Syme and Apelt 1990; Syme 2001) was used. 

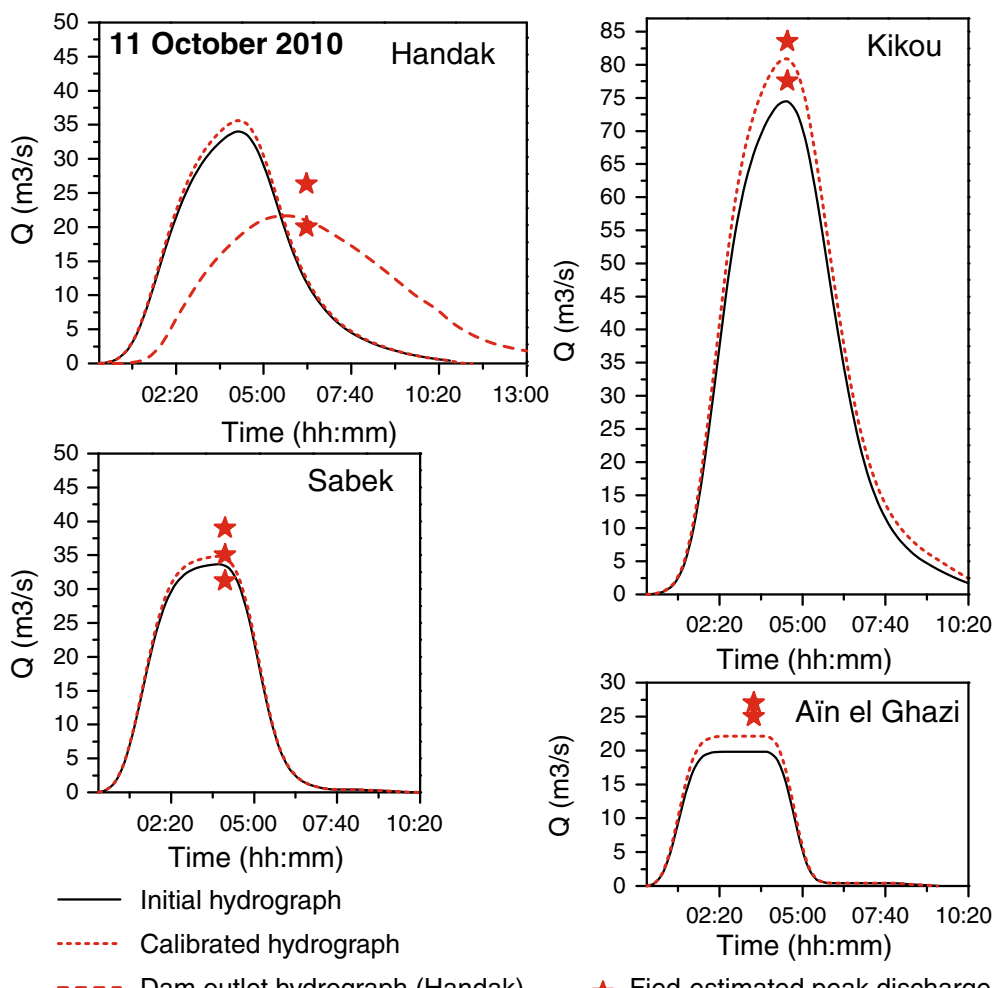

Fig. 9 Calibrated hydrographs for the 11 October event. The flood reduction dam set at the Handak outlet was accounted for. Peak discharge estimates were collected downstream of the dam. From: Werren (2013)

\subsection{Model presentation}

The 2D TUFLOW software is a hydrodynamic model that solves the full shallow water equations (SWE) (Balzano 1998; Bates and De Roo 2000) under the form:

$$
\begin{gathered}
\frac{\partial C}{\partial t}+\frac{\partial(H u)}{\partial x}+\frac{\partial(H v)}{\partial y}=0 \\
\frac{\partial u}{\partial t}+u \frac{\partial u}{\partial x}+v \frac{\partial u}{\partial y}-\mathcal{L}_{v}+g \frac{\partial C}{\partial x}+g u \frac{\sqrt{u^{2}+v^{2}}}{C^{2} H}-v \frac{\partial^{2} u}{\partial x^{2}}+\frac{\partial^{2} v}{\partial y^{2}}=F_{x} \\
\frac{\partial u}{\partial t}+u \frac{\partial v}{\partial x}+v \frac{\partial v}{\partial y}-\mathcal{L}_{u}+g \frac{\partial C}{\partial y}+g v \frac{\sqrt{u^{2}+v^{2}}}{C^{2} H}-v \frac{\partial^{2} u}{\partial x^{2}}+\frac{\partial^{2} v}{\partial y^{2}}=F_{y}
\end{gathered}
$$

where: $C=$ water surface level; $\partial x=$ depth-averaged velocity in the $x$ direction; $\partial y=$ depth-averaged velocity in the $y$ direction; $h=$ depth of water relative to a datum; $H=h+C=$ total depth; $\mathscr{L}=$ Coriolis parameter; $C=$ Chezy friction coefficient; and $F=$ external forces (wind, pressure) (Syme and Apelt 1990).

Initially developed for tidal process modelling, this model has been shown to provide very good solutions for riverine flooding, mainly because of its stability and robustness. 
Fig. 10 Modelled versus fieldestimated peak discharge for the two reference events at the selected cross sections.

Sbk1,2 = cross sections on Sabek; Ghz: = cross section on Aï el Ghazi; Hdk1,2 = cross sections on Handak;

Kik1,2 = cross sections on Kikou. From: Werren (2013)
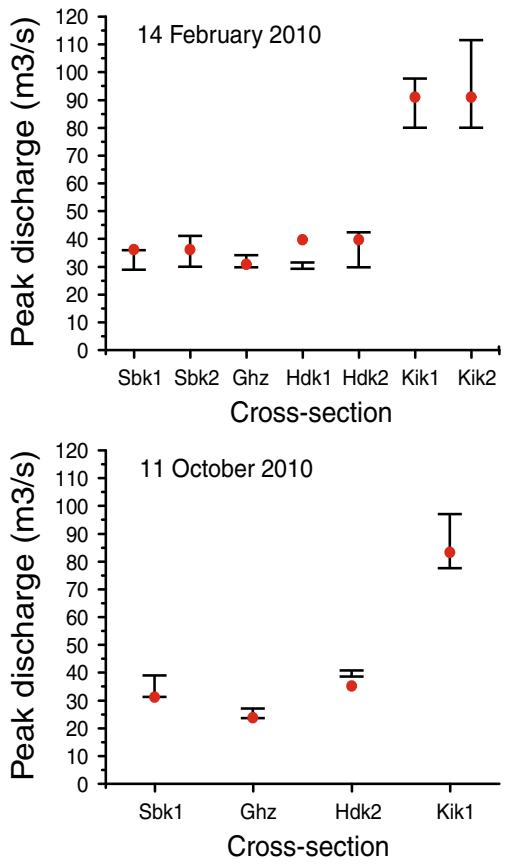

Ifield estimates variation $\bullet$ modelled value
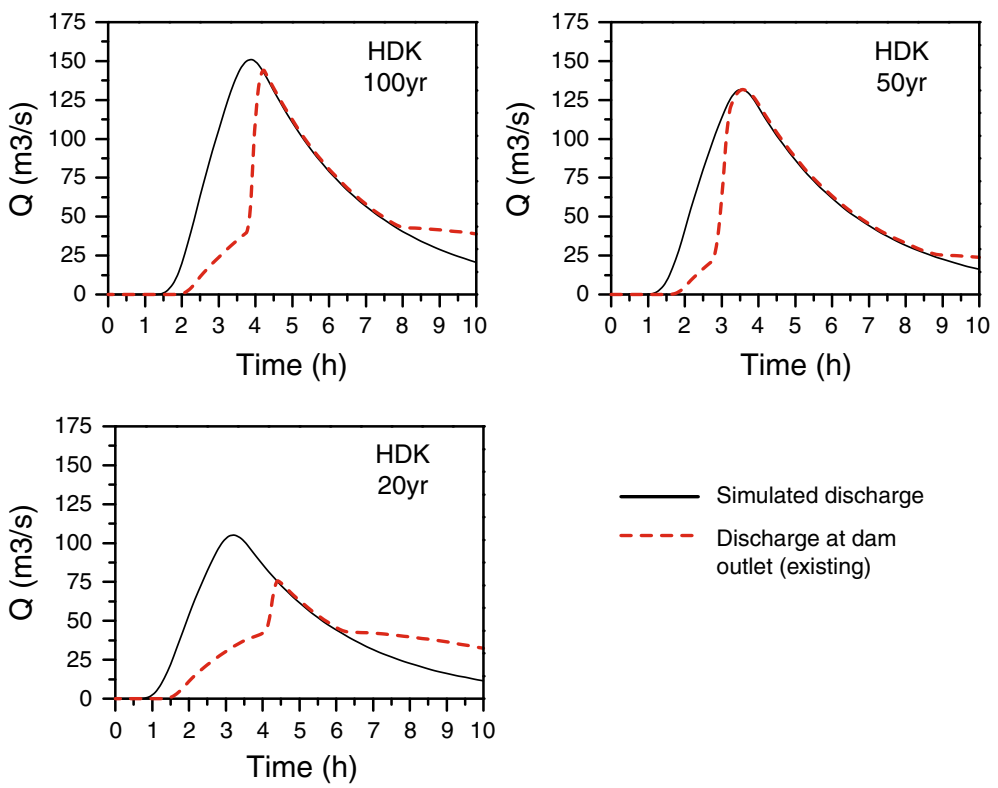

Simulated discharge

Discharge at dam outlet (existing)

Fig. 11 Flood hydrographs for 100-, 50-, and 20-year return period rainfall events using the initial and constant loss model. Dam effect on flood hydrograph was modelled using an elevation-storage function provided in HEC-HMS. Example for the Handak catchment 

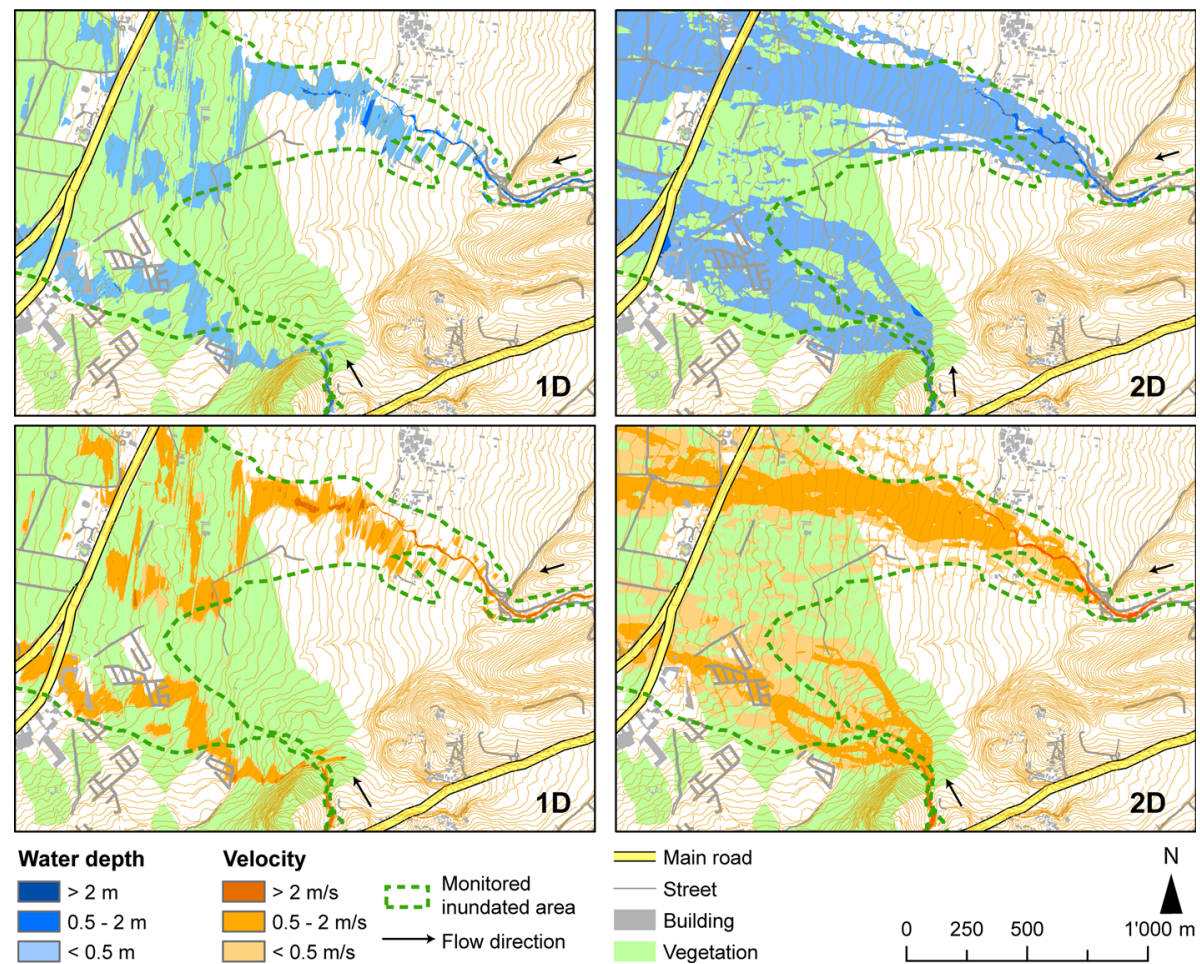

Fig. 12 Comparison between the one- and two-dimensional models results on an alluvial fan reach in Beni Mellal

The model computes depth-averaged velocity, water depth, and flood extent as basic elements for flood hazard assessment. TUFLOW can be accessed within the Aquaveo ${ }^{\mathrm{TM}}$ SMS (Surface-water Modelling Solution) interface that provides a GIS environment for hydraulic models.

\subsection{Topographic and land use data preparation}

A digital elevation model (DEM) was derived from contour lines and elevation points of the Beni Mellal urban plan (scale $=1: 2000$, contour line equidistance $=1 \mathrm{~m}$ ). As the elevation model could not provide a good representation of stream geometry, a manual channel cross section assignment was undertaken using field and remotely sensed information (aerial photographs, oblique photographs, field-collected cross section data). The obtained cross section information was then integrated into the DEM. Elevation data were imported into the Aquaveo ${ }^{\mathrm{TM}}$ SMS interface where all the TUFLOW input files were created. Land use information necessary for determining surface roughness was retrieved from a 2009 GeoEye image provided by Google Maps (Werren 2013). According to the geographical setting of the four streams that needed assessment, two simulation projects were generated. One project, codenamed BM, consisted of the urban reaches of the Sabek, Aïn el Ghazi, and Handak streams, as well as their junction with the Day stream. The second project, codenamed KIK, consisted of the Kikou stream. 


\subsection{Model setup}

The choice of parameter values was expected to achieve a compromise between model results accuracy, computational effort, and model stability (Table 1).

An elevation grid of cell size $3 \mathrm{~m}$ was generated (Table 1). This resolution was thought to balance model accuracy and computational effort for the practical purpose of this study. The model time step $\Delta t$ needed to be linked to the spatial resolution $\Delta x$ in order to achieve model stability (French 1985; Syme 2001). According to practice, in TUFLOW the required relationship is $\Delta t \leq \Delta x / 2$ (WBM Oceanics Australia 2007). TUFLOW uses a wetting and drying algorithm to manage the wetting front definition by providing criteria to declare one cell wet or dry (Balzano 1998; Yu and Lane 2006, WBM Oceanics Australia 2007). The wetting and drying parameters were selected as to achieve model stability; we considered therefore this parameter as an effective function (Lane 2005). Likewise, the Smagorinski coefficient for eddy viscosity (Smagorinsky 1963), used to describe flow turbulence when solving the shallow water equations, was set as an effective function.

Land use data were used as a base for assigning the Manning roughness coefficient $n$. Roughness coefficients were estimated according to Chow (1959) for several land use classes (Table 2). Buildings were assigned $n=3$ in order to account for their flow-obstructing role. This approach is widely used in hydraulics modelling to represent structures when resolution of the elevation data cannot account for them properly ( $\mathrm{Yu}$ and Lane 2006).

Boundary conditions were set at the two ends of the modelled domain. The upstream boundary condition consisted of flood hydrographs for the 11 October 2010 monitored flood event and, after model optimization, for the flood hazard assessment reference events as obtained during the previous stage. Downstream boundary condition consisted of a control water level as computed from channel slope.

Table 1 Assignment of the model parameters for the two simulation projects (BM and KIK), and the objective to be attained

\begin{tabular}{llll}
\hline Parameter & BM & KIK & Objective \\
\hline Cell size (m) & 3 & 3 & Output accuracy, computational effort \\
Time step (s) & 1.5 & 1.5 & Model stability, accuracy, computational effort \\
Wet/dry depth (m) & 0.025 & 0.025 & Model stability, accuracy \\
Cell side wet/dry depth (m) & 0.05 & 0.05 & Model stability, accuracy \\
Eddy viscosity (Smagorinsky) & 0.4 & 0.2 & Model stability, accuracy \\
\hline
\end{tabular}

Table 2 Manning coefficient (n) according to Chow (1959) for 7 land use classes

\begin{tabular}{lc}
\hline Land use class & $N$ \\
\hline Concrete channel & 0.01 \\
"Clean" channel & 0.03 \\
"Rough channel" & 0.04 \\
Urban surface (streets) & 0.02 \\
Grassy surface & 0.06 \\
Trees, olive plantation & 0.08 \\
Buildings & 3.00 \\
\hline
\end{tabular}




\subsection{Calibration by field investigations}

The maximum flood extent for the 11 October 2010 event was mapped in the field in order to calibrate the model. This approach could only provide partial calibration, as no stage data could be retrieved during the mapping process. The mapped flood extent allowed us to optimize the model by exploring the impact of model parameter values on output accuracy. Moreover, hydro-geomorphic mapping of the active processes provided verification criteria for the model's ability to represent flow processes correctly on the complex alluvial fan surfaces.

\subsection{Model sensitivity analysis and extrapolation}

A basic OFAT analysis (Morris 1991) was undertaken in order to identify the model parameters impacting most upon model predictions and to inform the choice of eventual parameter values used. This was undertaken by multiplying each initial parameter value by 0.5 and 2. Accuracy was estimated with measures of agreement utilized by similar studies: kappa (Cohen 1960; Yu and Lane 2006), F (Bates and de Roo 2000; Yu and Lane 2006), and overall accuracy (Yu and Lane 2006). Flow process representation was also judged on a visual basis, by comparing the model results with the hydro-geomorphic map. This analysis was used to adjust model parameter values. The calibrated model was applied to simulate floods related to rainfall events of 20-, 50-, and 100-year return-time period.

\subsection{Results}

The model sensitivity analysis focussed on four parameters: grid resolution, Manning roughness coefficient $n$, wetting and drying algorithm coefficients, and Smagorinsky coefficient for eddy viscosity (Tables 3,4).

Sensitivity analysis did not identify parameters that were clearly impacting upon model performance. It is not necessary to increase spatial resolution for the two models: the initial $3-\mathrm{m}$ resolution performed well in accuracy and process representation; lowering the resolution $(6 \mathrm{~m})$ would induce poorer channel representation, while higher resolution $(2 \mathrm{~m})$ induces the over interpretation of topographic lows (Fig. 13). Lowering roughness values induced lower accuracy and the overestimation of flood extents, while greater friction values did not affect accuracy. However, they resulted in water ponding on flat surfaces on

Table 3 Value of several accuracy estimators according to changes in parameter values

\begin{tabular}{llllll}
\hline Parameter & Variation & $K$ & $K_{1}$ & $F$ & $O$ \\
\hline Resolution & $3 \mathrm{~m}$ & 32.45 & 30.51 & 46.22 & 66.45 \\
& $6 \mathrm{~m}$ & 30.62 & 28.81 & 45.18 & 65.54 \\
Roughness & $n / 2^{\mathrm{a}}$ & 21.87 & 19.58 & 39.2 & 61.31 \\
& $n^{*} 2$ & 31.42 & 30.91 & 46.51 & 65.85 \\
Eddy viscosity & 0.4 & 32.45 & 30.51 & 46.22 & 66.45 \\
& 0.8 & 31.76 & 29.51 & 45.57 & 66.13 \\
\hline
\end{tabular}

BM project. $K$ kappa index, $K 1$ kappa index for wet cells, $F F$ accuracy measure, $O$ overall accuracy measure. Values for all indexes range from 0 to 100

a $n$ varies according to land use classes (see Table 2) 
Table 4 Value of several accuracy estimators according to changes in parameter values

\begin{tabular}{llllll}
\hline Parameter & Variation & $K$ & $K_{1}$ & $F$ & $O$ \\
\hline Resolution & $2 \mathrm{~m}$ & 25.25 & 26.16 & 35.98 & 65.12 \\
& $3 \mathrm{~m}$ & 22.9 & 38.98 & 40.11 & 59.8 \\
& $6 \mathrm{~m}$ & 30.34 & 29.79 & 38.76 & 67.65 \\
Roughness & $n / 2$ & 15.41 & 22.37 & 34.70 & 57.24 \\
& $n^{*} 2$ & 25.17 & 35.02 & 39.56 & 62.52 \\
Eddy viscosity & 0.2 & 22.9 & 38.98 & 40.11 & 59.8 \\
W-D (depth, cell side in meters) & 0.4 & 28.72 & 30.19 & 38.25 & 66.62 \\
& $0.0125,0.025$ & 30.04 & 31.22 & 38.88 & 67.34 \\
& $0.05,0.1$ & 25.17 & 35.02 & 39.56 & 62.52 \\
\hline
\end{tabular}

Kikou project. $K$ kappa index, $K 1$ kappa index for wet cells, $F F$ accuracy measure, and $O$ overall accuracy measure. Values for all indexes range from 0 to 100

distal fan regions (Fig. 14). Therefore, the initial values offer a good compromise for the two models. Third, eddy viscosity does not significantly influence accuracy or process representation (Fig. 15). Nevertheless, this parameter represents an effective function for the model, i.e. its values directly impact model stability. Finally, wetting and drying parameter values seem to regulate flood extent and local water depth estimations (Fig. 16). However, this is mainly when the wetting and drying parameter is doubled to largely implausible values.

As we performed simulations with half and double the initial parameter values, we note that this analysis is dependent on the chosen range of values for each parameter. Therefore, not exploring larger parameter ranges might have an effect on the model performance. Nevertheless, the initial parameter choice was justified by the need to achieve the necessary model precision with reasonable computation costs. With the default parameter values, flood intensity maps, in terms of flood maximum water depth and velocity, were produced for the reference events of 20-, 30-, and 100-year return periods (Fig. 17).

\section{Flood hazard map of Beni Mellal}

\subsection{Hazard assessment procedure}

The design of the flood hazard map is based on Swiss guidelines (Loat and Petrascheck 1997, ARE, OFEG, OFEFP 2005). Hazard assessment was performed by adapting the Swiss hazard matrix that convolutes hazard magnitude and probability of occurrence (Fig. 18). The Swiss hazard matrix contains information on hazard intensity and relates to a series of land use prescriptions through the matrix colour code. Within the Swiss hazard assessment guidelines, red zones are prohibited for further urban development, in particular building of new houses, blue zones allow building under specific safety conditions, while the yellow zones are hazard awareness-making areas (Loat and Petrascheck 1997; Lüthi 2004; Penelas et al. 2008). The Swiss guidelines provide homogeneous thresholds for delimiting classes of magnitude and probability, as shown in Tables 5 and 6. In this study, we applied different probability thresholds, according to the Moroccan practice of flood risk mitigation (Table 6). 

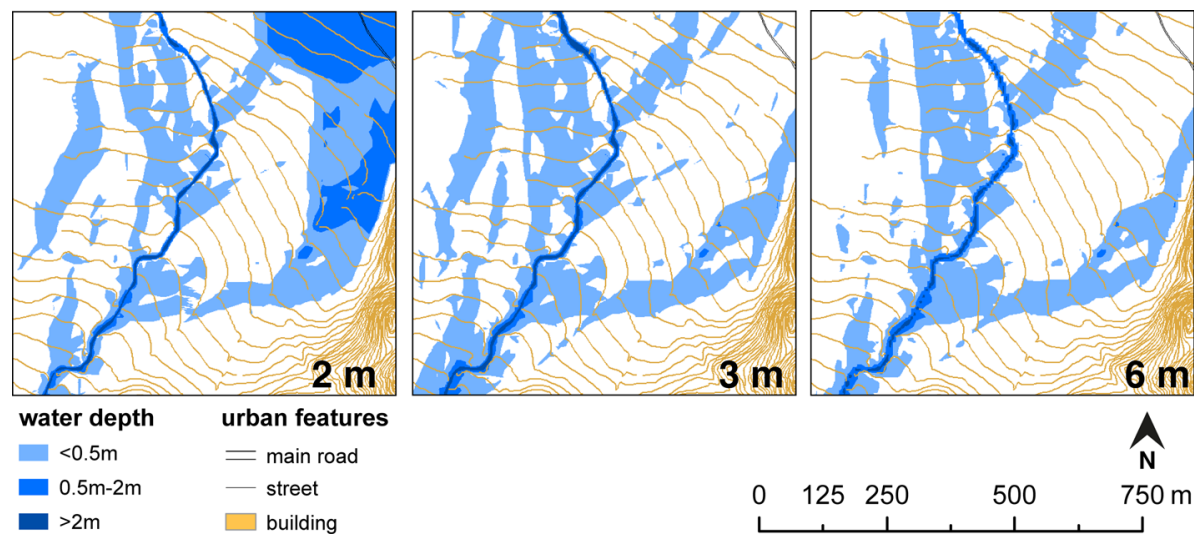

Fig. 13 Effect of grid resolution on flow process representation. Example of the Kikou reach (KIK project)
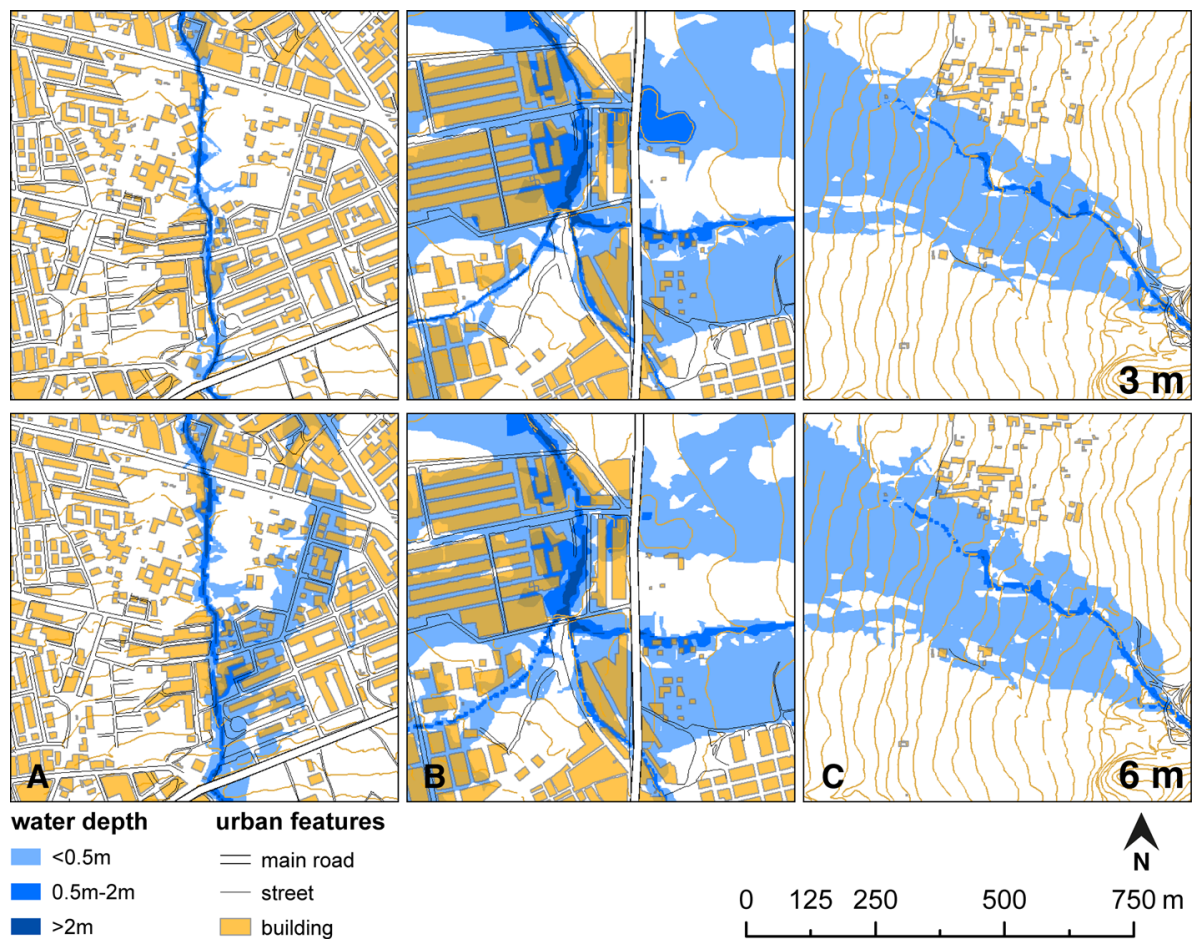

Fig. 14 Effect of grid resolution on flow process representation. Example of $\mathbf{A}$ the Handak reach, $\mathbf{B}$ the Day confluence zone, and $\mathbf{C}$ the Sabek alluvial fan reach (BM project)

\subsection{Results}

A flood hazard magnitude map (example in Fig. 19) was produced, by combining flood magnitude maps of the three reference scenarios. The three maps were merged using the 

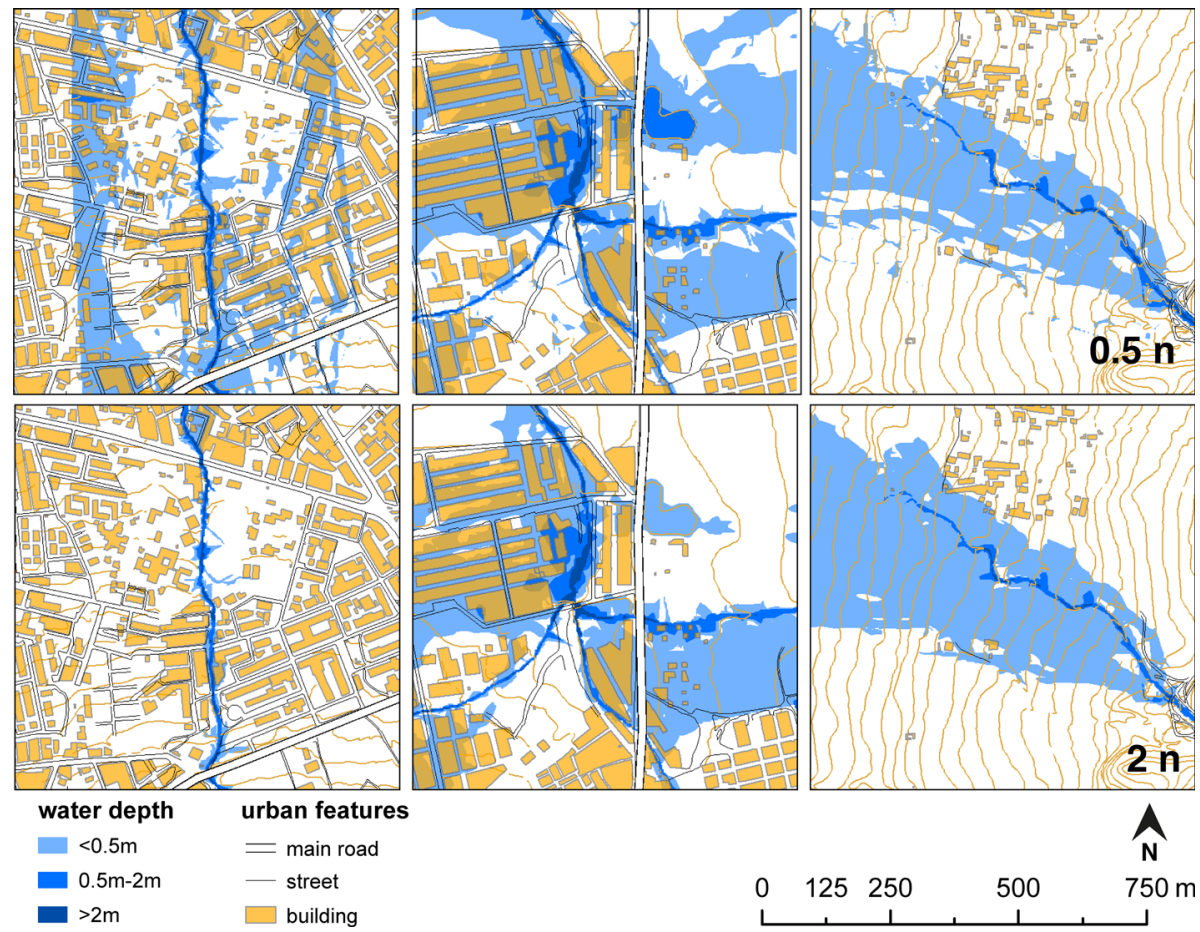

Fig. 15 Effect of changing the $n$ roughness coefficient on flow processes representation. Example of the BM project

Union tool in ESRI ArcMap. Highest intensity value was assigned for each map cell. Maps of the maximum flood extent for the reference scenarios were merged to determine a flood probability map (Fig. 19) Then, the intensity and probability maps were intersected, according to the hazard convolution matrix, resulting in a 9-class map which was finally classified into three hazard zones to obtain a flood hazard map (Fig. 20).

The hazard map is a decision-making tool useful for hazard-aware urban development in the studied area. It has an indicative character due to uncertainties related to input data scarcity and imprecisions, and to inherent uncertainties related to the modelling process.

\section{Discussion}

This study's objective was to assess and map flood hazard concerning an urban area in conditions of scarce data, by combining hydro-geomorphic knowledge and hydrologicalhydraulic modelling. In this context, hydrological and hydraulic modelling of the stream behaviour proved to be essential for the hazard assessment process.

We suggest that good knowledge of catchment soil and land cover conditions and better flood understanding through post-flood campaigns and flood deposit mapping and characterization is mandatory so as to compensate for the lack of data and therefore reducing model uncertainty. Hydro-geomorphic information is likely to enhance hazard assessment in several ways. First, hazard-prone areas are delimited, and thus hazard assessment 

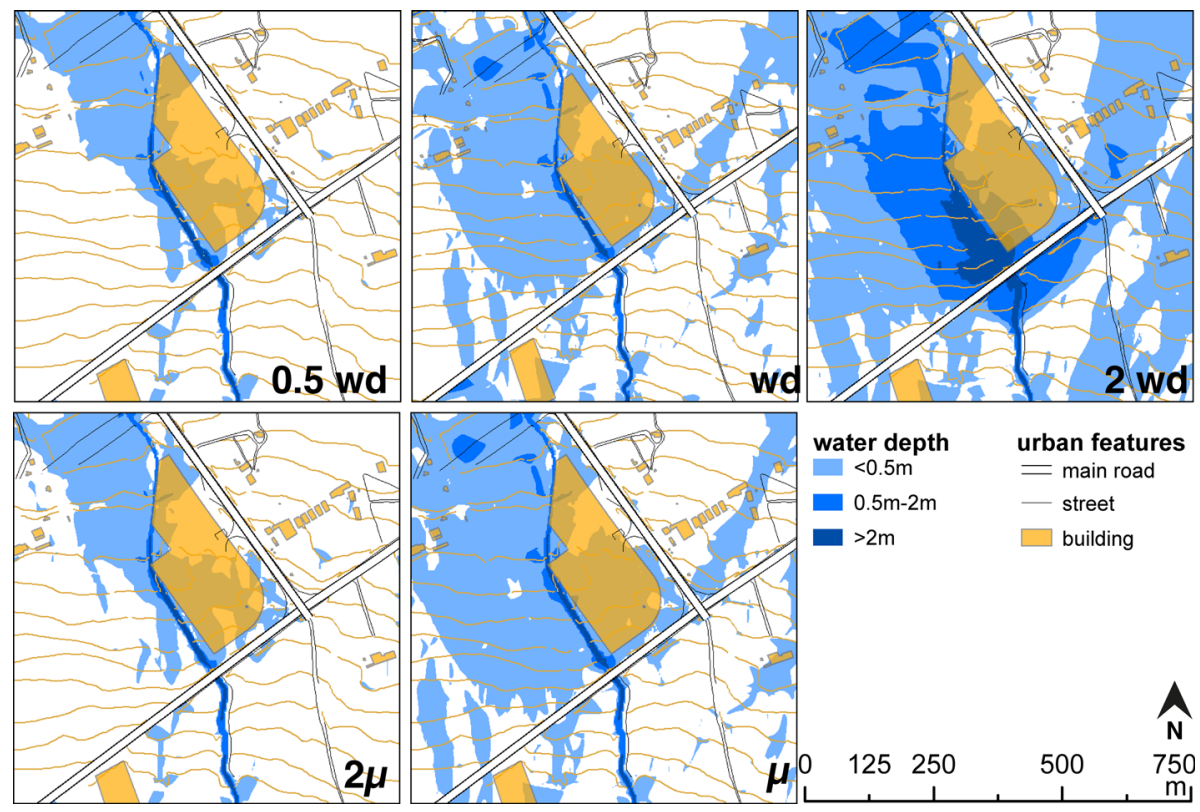

Fig. 16 Effect of changing the wetting and drying (wd) and eddy viscosity $(\mu)$ parameters on flow processes representation. Example of the KIK project

through modelling can focus on the areas of interest. Then, knowledge of erosion-deposition patterns, as well as preliminary assessment of process intensity, is useful during the modelling stage, in order to compare the modelled process representation to field data. Finally, mapped flood extent and field-estimated peak discharge provide calibration means for the models. As a shortcoming, mapping and imprecision in estimates add uncertainty to the final modelled result.

Through hydrological modelling of two known events, this study's goal was to realistically depict flood behaviour in the four catchments that drain Beni Mellal. Their flashflood-prone character was well represented in the resulting hydrographs. The use of several infiltration methods allowed choice of the most appropriate model for the studied catchments. For instance, the SCS-CN method, although used in hydrological studies in Morocco (e.g. Tramblay et al. 2012), significantly underestimated peak discharges even though $\mathrm{CN}$ values were relatively high in the four catchments (74.5-85.1). Moreover, it was demonstrated that the Green-Ampt model needs exhaustive calibration of its most sensitive parameter, i.e. the saturated conductivity, in order to achieve good performance in shallow soil conditions (Liu et al. 2011). Finally, the chosen method, i.e. the initial and constant loss rate method, is widely used in semi-arid catchments in Australia (Mahbub and Monzur 2009) and was found to perform better than the Green-Ampt method in semiarid conditions in Iran (Arekhi et al. 2011). Further studies in similar locations should consider the use of this method in order to assess its applicability in a larger extent.

Peak discharge estimates obtained during post-flood measure campaigns provide means for partial calibration of the model. However, peak discharge value ranges were used rather than unique values, in order to account for uncertainties related to field measurements and model performance. 


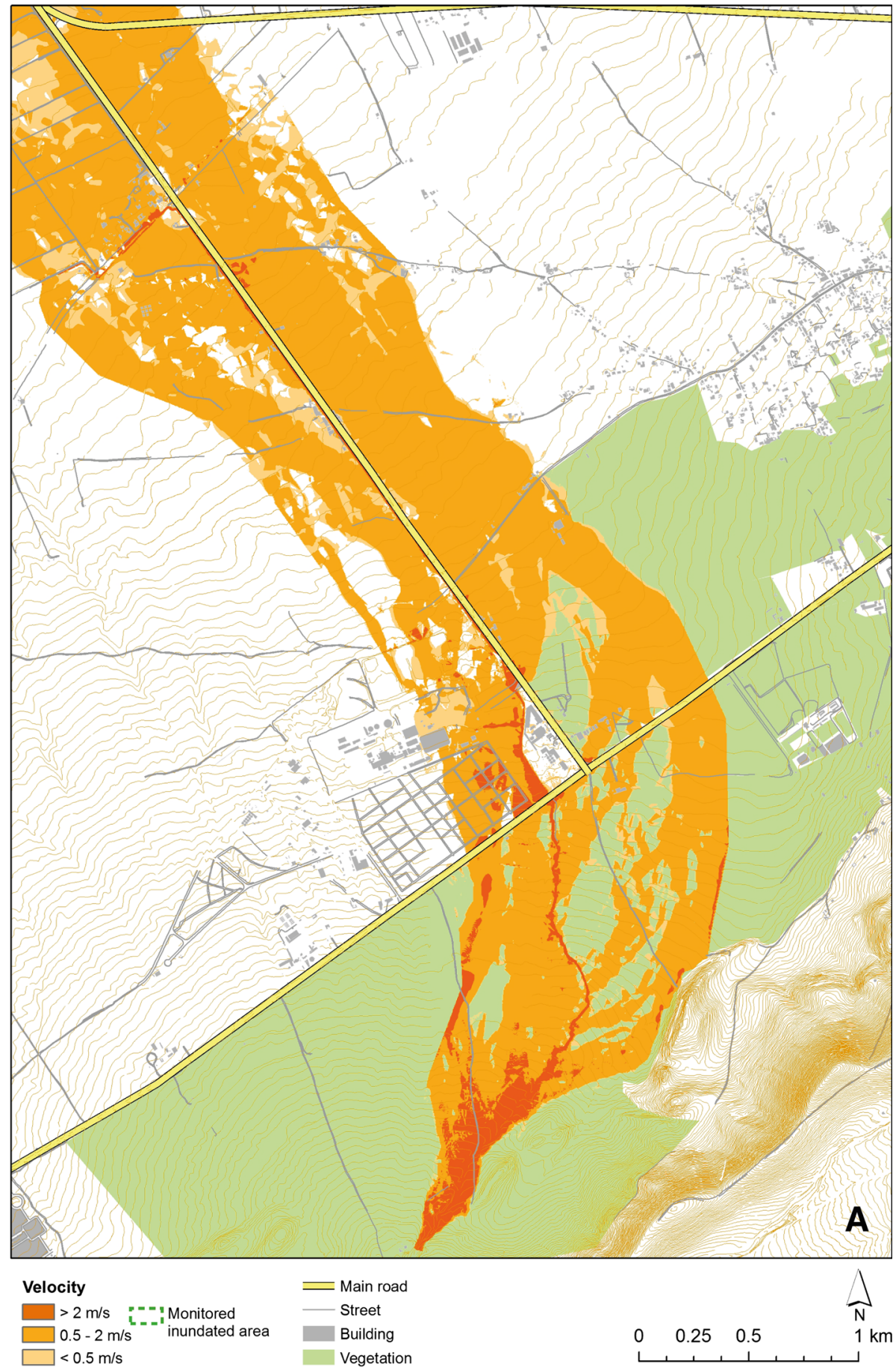


Fig. 17 Flood hazard intensity: A maximum velocity and $\mathbf{B}$ water depth for the 100-year scenario. Example of the Kikou stream. Intensity classes were assigned according to the Swiss guidelines (Loat and Petrascheck 1997)

Results obtained by the combination of hydrological and hydro-geomorphological methodologies better depict catchment hydrological behaviour than separate use of these techniques. Knowledge of the natural processes is essential at every modelling stage in order to legitimate the choices made within a model. However, this approach requires interdisciplinary skills and a better involvement of geomorphologists in hazard assessment procedures, especially in regions where scarce data hinder hydrological modelling.

The second important assessment stage, i.e. hydraulic flood modelling within the urban area of Beni Mellal, aimed at predicting flood hazard in terms of flood magnitude for three scenarios representing events of low, medium, and high recurrence probability. One known event was simulated using field-collected calibration data and hydro-geomorphic information of possible flood intensity. The model was then optimized for use in hypothetical flood scenarios by tuning its main parameters. We suggest that the choice of a 3-m grid is fairly precise and satisfactory for flood process representation in urban areas as was also demonstrated by Hunter et al. (2008). As demonstrated by this study, this resolution is also pertinent for the representation of flood processes on fan surfaces and we therefore recommend the use of minimum 3-m grid resolution in further similar studies. The roughness parameter choice is based on land use classes in order to depict the variation in surface friction. It has been shown in the literature (Lane 2005; Yu and Lane 2006) that the roughness coefficient is often used as an effective parameter for model calibration as its actual relationship to real surfaces is difficult to assess. Indeed, this empirical parameter stems from steady flow assumptions applied to unsteady flows (French 1985). The relative sensitivity of this parameter suggests that exploring a larger value range could enhance the calibration results, as it was demonstrated for instance by $\mathrm{Yu}$ and Lane (2006). Nonetheless, we consider that in a context of relatively high uncertainty related mainly to the available topographic data, using too large roughness coefficients in the calibration process risks over-parameterizing the model.

The final output of the hydraulic modelling stage, i.e. flood extent, maximum water depth, and maximum velocity maps for three reference scenarios, provided essential measurable data for hazard mapping that could not be obtained using solely geomorphic or descriptive methods. Nonetheless, field-collected flood extent and hydro-geomorphic data provided an essential means for validating the model and allowed us to better understand internal model uncertainties. We suggest that in areas similar to our study site, modelling methodologies should integrate geomorphic and eventually geological mapping to their protocols in order to achieve process understanding and finally to reduce uncertainties.

The Beni Mellal flood hazard map, obtained by intersecting cartographic representations of flood magnitude and probability of occurrence, is a pioneering document, being the first such map published in Morocco. A sound decision-making tool, the hazard map, can provide planners with a comprehensive set of information related to the spatial imprint and consequences of floods within the study site. One must notice, however, that the hazard map reflects uncertainties accumulated during the successive assessment stages. As such, this hazard map is more likely to play a decision-making role for subsequent planning rather than being used directly within specific building procedures. 


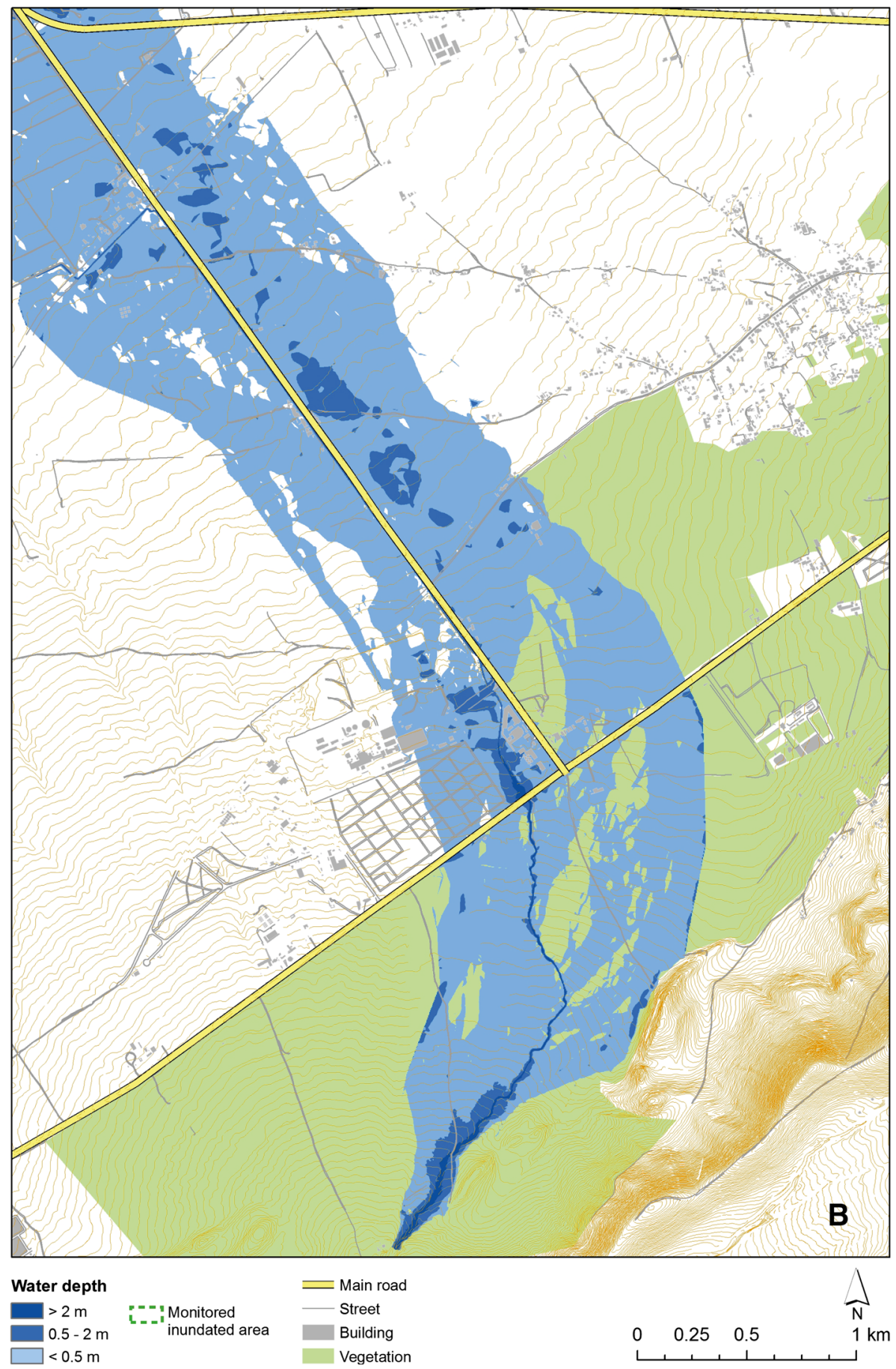

Fig. 17 continued 
Fig. 18 Swiss hazard matrix. Source: ARE, OFEG, OFEFP (2005)

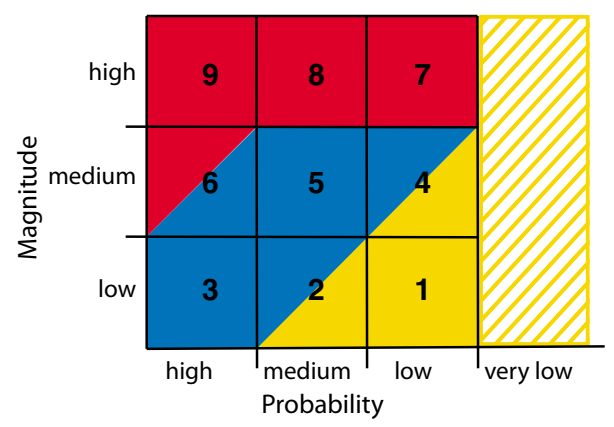

Table 5 Flood hazard intensity thresholds according to Swiss guidelines

\begin{tabular}{llll}
\hline Magnitude threshold & Low & Medium & High \\
\hline Static flood: water depth & $H<0.5 \mathrm{~m}$ & $0.5<H<2 \mathrm{~m}$ & $H>2 \mathrm{~m}$ \\
Dynamic flood: water depth * velocity & $H v<0.5 \mathrm{~m}^{2} / \mathrm{s}$ & $0.5<H v<2 \mathrm{~m}^{2} / \mathrm{s}$ & $H v>2 \mathrm{~m}^{2} / \mathrm{s}$ \\
\hline
\end{tabular}

From ARE, OFEG, OFEFP (2005)

Table 6 Flood hazard probability thresholds according to Swiss guidelines (ARE, OFEG, OFEFP 2005) and adaptation to this case study

\begin{tabular}{llcc}
\hline Probability threshold & Low (year) & Medium (year) & High (year) \\
\hline Recurrence period (this study) & 100 & 50 & 20 \\
Recurrence period (Swiss method) & 300 & 100 & 30 \\
\hline
\end{tabular}

\section{Conclusion}

Predicting flood hazards in semi-arid, ungauged regions is challenging. In this context, using alternative data sources such as remotely sensed data and building a knowledge based on catchment properties and related hydrodynamic behaviour are essential steps in order to provide more realistic hazard scenarios for planning purposes and ultimately enhance flood risk mitigation. This study endeavoured to produce such realistic scenarios by intensive use of field-monitored data as a means of validating model performance. Field data enhanced the modelling process and the final result by providing arguments for the use of models that better depict actual processes as compared to the techniques classically in use in the study area. A series of uncertainties were identified, and the models were optimized according to the gathered field knowledge. Finally, a flood hazard map was designed for the study site in Beni Mellal. A pioneering document, this map provides a sound basis for decision-making in the sense of a more hazard-aware urban development.

Uncertainty in hazard assessment requires special attention as hazard maps are meant to have important spatial consequences when integrated in urban planning. In this project, uncertainty quantification was impossible, however uncertainty sources were identified. Thus, uncertainties can be reduced by the use of better datasets (e.g. digital terrain models) 


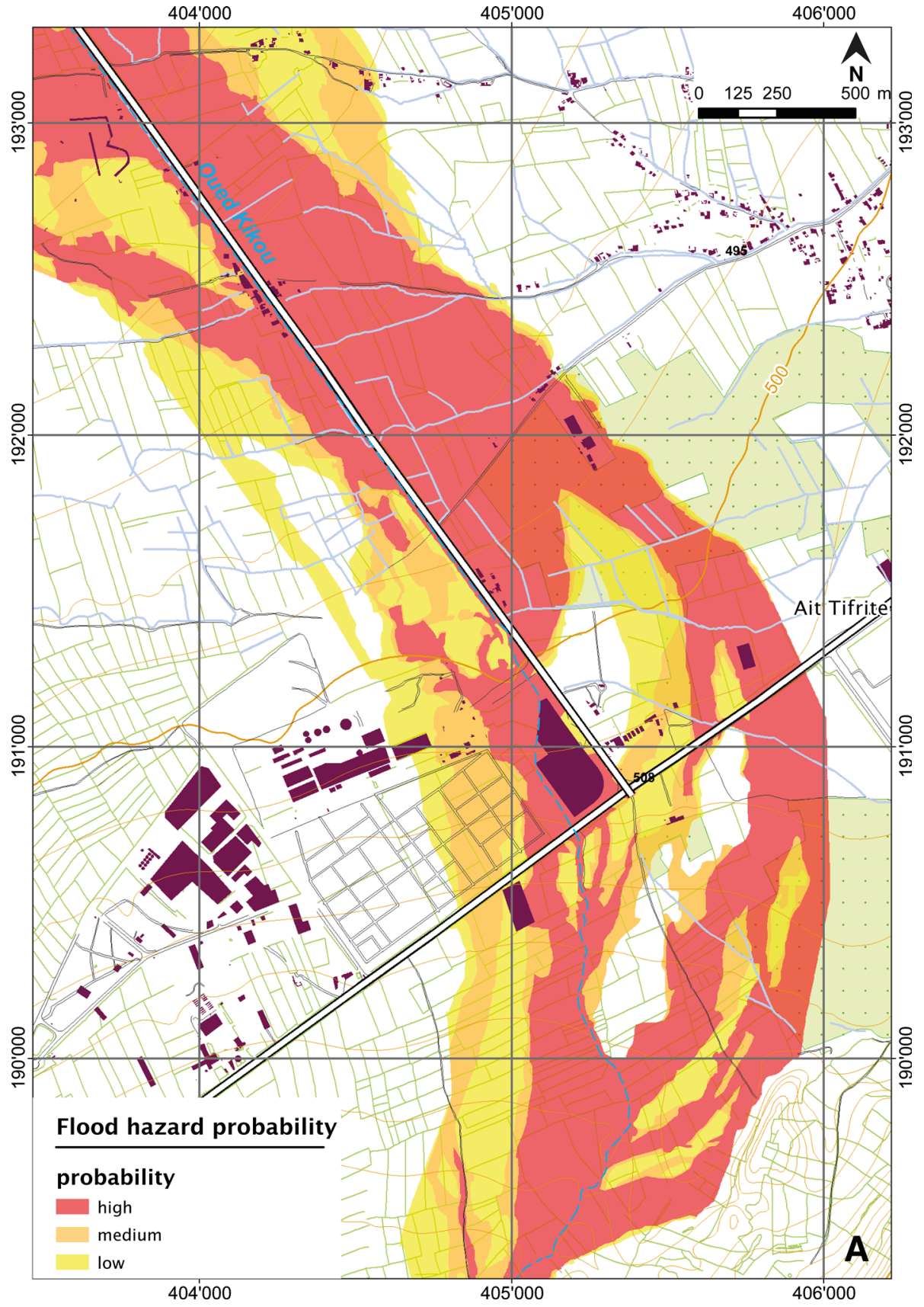

Fig. 19 Flood hazard probability (A) and magnitude (B) maps. Example of the Kikou stream. Buildings are designed in purple on the map 


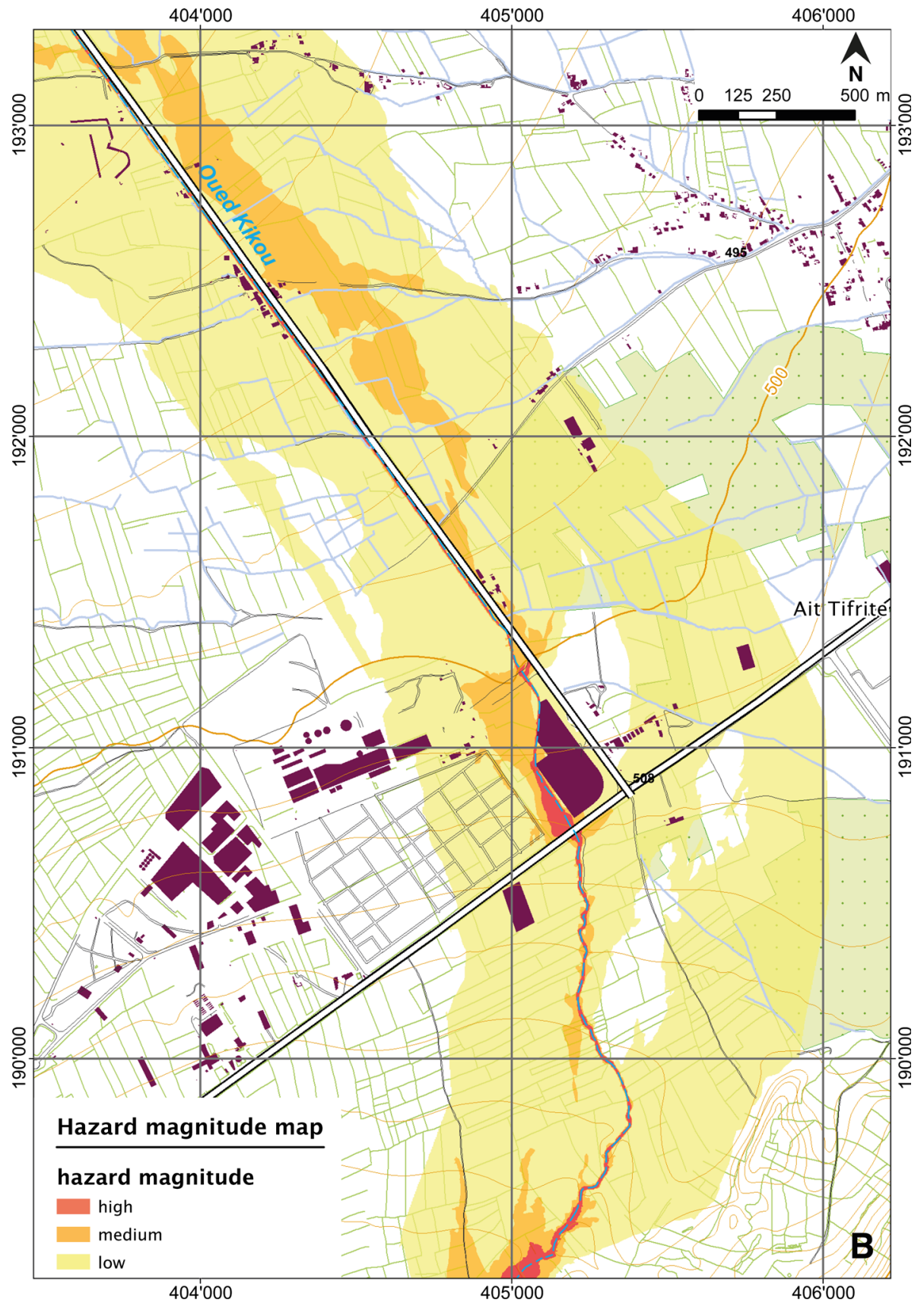

Fig. 19 continued 


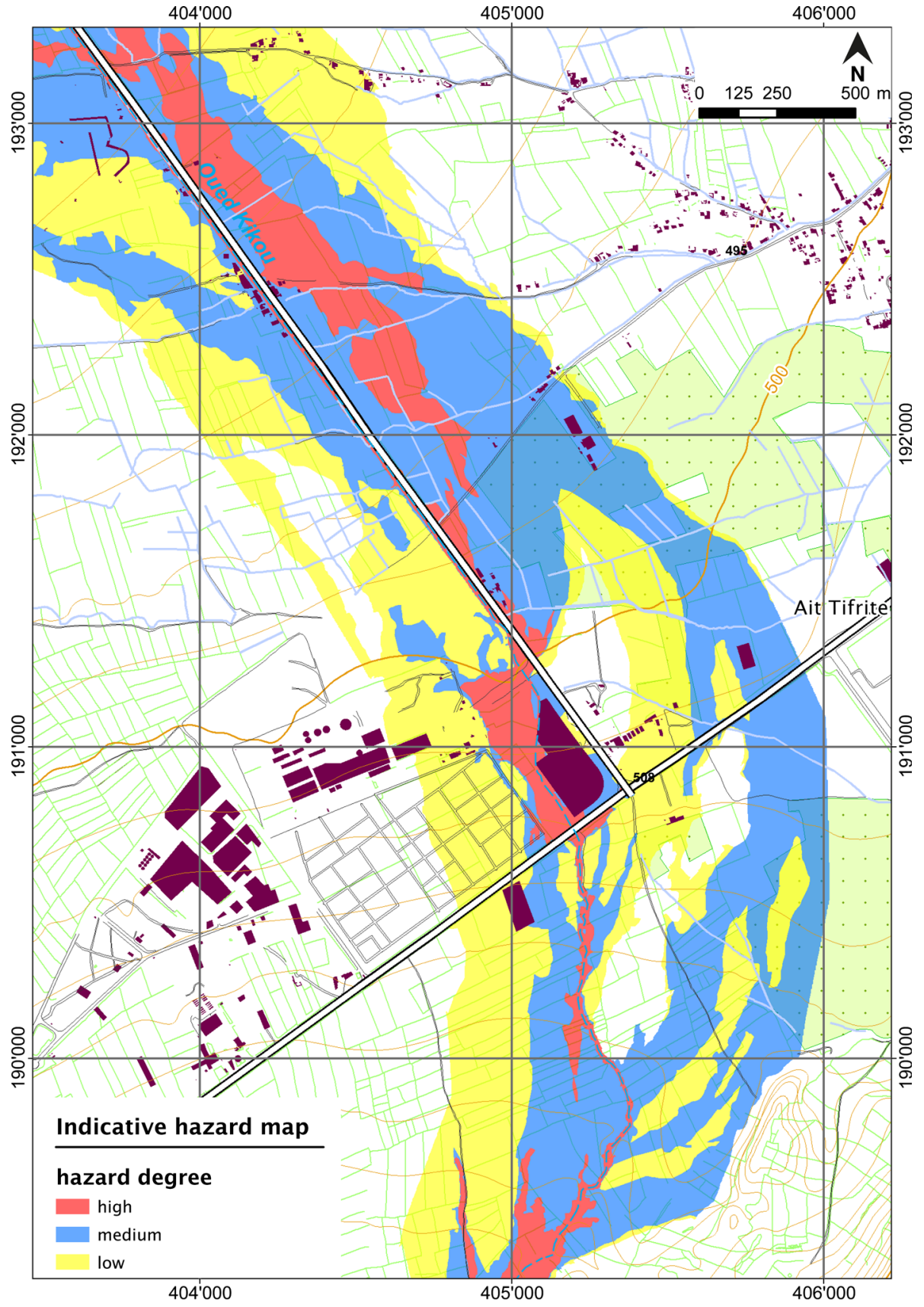

Fig. 20 Flood hazard map. Example of the Kikou stream. Buildings are designed in purple on the map 
or by better access to data (as it was experienced in this project, data scarcity can be relative, i.e. data exist but are difficult to access). Moreover, field investigations such as those presented above need to be run on a systematic basis for longer periods of time in order to build flood databases for model calibration.

In order to make hazard maps widely available, homogeneous guidelines for map design should be implemented within in the studied context. That is, adaptations to the local needs and realities are necessary (e.g. rethinking the threshold scale to adapt it to specific building regulations, adapting the colour code to local perceptions, negotiating the desired map precision in order to consider inherent uncertainties).

Acknowledgments This research was financed by the Swiss agency for Development and Cooperation (SDC), Project Gestion du risque d'inondation dans deux bassins versants marocains: Fès et Beni Mellal (2009-2013).

Open Access This article is distributed under the terms of the Creative Commons Attribution 4.0 International License (http://creativecommons.org/licenses/by/4.0/), which permits unrestricted use, distribution, and reproduction in any medium, provided you give appropriate credit to the original author(s) and the source, provide a link to the Creative Commons license, and indicate if changes were made.

\section{References}

ABHOER (2004) Protection contre les inondations dans la zone d'action de l'Agence dubassin hydraulique Oum-er-Rhbia, Agence du bassin hydraulique Oum-er-Rhbia (AHOER), Beni Mellal

ADI (2004) Etude de protection contre les inondations. Etude hydraulique et propositions d'aménagement. Province de Beni Mellal, Compagnie d'Aménagement Agricole et Développement Industriel (A.D.I), Beni Mellal

ARE, OFEG, OFEFP (2005) Aménagement du territoire et dangers naturels, recommandations. Office fédéral du développement territorial (ARE), Office fédéral des eaux et de la géologie (OFEG) et Office fédéral de l'environnement, des forêts et du paysage (OFEFP), Berne

Arekhi S, Rostamizad G, Rostami N (2011) Evaluation of HEC-HMS methods in surface runoff simulation (Case study: Kan watershed, Iran). Adv Environ Biol 5(6):1316-1321

Balzano A (1998) Evaluation of methods for numerical simulation of wetting and drying in shallow water flow models. Coast Eng 34:83-107

Bates PD, De Roo APJ (2000) A simple raster-based model for flood inundation simulation. J Hydrol 236:54-77

Borga M, Anagnostou EN, Blöschl G, Creutin J-D (2010) Flash floods: observations and analysis of hydrometeorological controls. J Hydrol 394(1):1-3

Bouchaou L (1997) Contribution à la connaissance de l'aquifère karstique de l'Atlas de Beni Mellal (Maroc). Karst hydrology (Proceedings of workshop W2 held in Rabat, Morroco, April-May 1997), IAHS publications 247:117-126

Chave S, Ballais JL (2006) From hydrogeomorphology to hydraulics computations: a multidisciplinary approach of the flood hazard diagnosis in the Mediterranean zone. Zeitschrift für Geomorphologie 4(50):523-540. doi:10.1127/zfg/50/2006/523

Chow VT (1959) Open channel hydraulics. McGraw-Hill, New York

Cohen J (1960) A coefficient of agreement for nominal scales. Educ Psychol Meas 1(20):37-46

El Khalki Y, Benyoucef A (2005) Crues et inondations de l'oued El Handak: genèse, impact et propositions d'aménagement (Atlas de Beni Mellal). Etudes de Géographie physique 32:47-61

El Khalki Y, Hafid A (2002) Turbidité, indicateur du fonctionnement perturbé du géosystème karstique de Beni Mellal (Moyen Atlas méridional, Maroc). Karstologia 40:39-44

El Khalki Y, Taïbi AN, Benyoucef A, El Hannani M, Hafid A, Mayoussi M, Zmou A, Ragala R, Geroyannis H (2005) Processus d'urbanisation et accroissement des risques à Beni Mellal (Tadla-Azilal, Maroc): apports des SIG et de la télédétection. Mosella 1-4(30):147-161

Fernandez-Lavado C, Furdada G, Marqués MA (2007) Geomorphological method in the elaboration of hazard maps for flash-floods in the municipality of Jucuaran (El Salvador). Nat Hazard Earth Syst Sci $7: 455-465$ 
French RH (1985) Open-channel hydraulics. McGraw-Hill, New York

Gaume E, Borga M (2008) Post-flood field investigations in upland catchments after major flash-floods: proposal of a methodology and illustrations. J Flood Risk Manag 1:175-189

Gaume E, Livet M, Desbordes M, Villeneuve J-P (2004) Hydrological analysis of the river Aude, France, flash flood on 12 and 13 November 1999. J Hydrol 286:135-154

Gaume E, Bain V, Bernardara P, Newinger O, Barbuc M, Bateman A, Blaškovicov L, Blöschl G, Borga M, Dumitrescu A, Daliakopoulos I, Garcia J, Irimescu A, Kohnova S, Koutroulis A, Marchi L, Matreata S, Medina V, Preciso E, Sempere Torres D, Stancalie G, Szolgay J, Tsanis I, Velasco D, Viglione A (2009) A collation of data on European flash floods. J Hydrol 367:70-78

Giorgi F, Lionello P (2008) Climate change projections for the Mediterranean region. Global Planet Change 63:90-104

Green WH, Ampt G (1911) Studies of soil physics, part I-the flow of air and water through soils. J Agric Sci $4: 1-24$

Hjelmfelt AT (1980) Curve number procedure as infiltration method. J Hydraul Div ASCE HY6(106): 1107-1110

Hong Y, Adler RF, Negri A, Huffman GJ (2007) Flood and landslide applications of near real-time satellite rainfall estimation. J Nat Hazards 43:285-294

Hooke JM (2006) Human impacts on fluvial systems in the Mediterranean region. Geomorphology 79:311-335

House PK (2005) Using geology to improve flood hazard management on alluvial fans—an example from Laughlin, Nevada. JAWRA J Am Water Resour As 41(6):1431-1447

House PK, Buck BJ, Ramelli AR (2007) Geologic assessment of piedmont and playa flood hazards in the Ivanpah Valley Area, Clark County, Nevada. Bureau of Mines and Geology, Nevada

Huffman GJ, Adler RF, Bolvin DT, Nelkin EJ (2009) The TRMM multi-satellite precipitation analysis (TMPA). In: Hossain F, Gebremichael M (eds) Satellite applications for surface hydrology. Springer, Berlin, pp 1-23

Hunter NM, Bates PD, Neelz S, Pender G, Villanueva I, Wright NG, Liang D, Falconer RA, Lin B, Waller S, Crossley AJ (2008) Benchmarking 2D hydraulic models for urban flooding. Water Manag 1(161):13-30. doi:10.1680/wama.2008.161.1.13

IPCC (2012) Managing the risks of extreme events and disasters to advance climate change adaptation. A special report of working groups I and II of the Intergovernmental Panel on Climate Change. In: Field CB, Barros V, Stocker TF, Qin D, Dokken DJ, Ebi KL, Mastrandrea M-D, Mach KJ, Plattner GK, Allen SK, Tignor M, Midgley PM (eds.) Cambridge University Press, Cambridge

Jenny H (1941) Factors of soil formation, a system of quantitative pedology. McGraw-Hill, New York

Lane SN (2005) Roughness-time for a re-evaluation? Earth Surf Process Land 30:251-253

Latron J, Llorens P, Gallart F (2009) The hydrology of Mediterranean mountain areas. Geogr Compass 3(6):2045-2064

Liu G, Craig JR, Soulis ED (2011) Applicability of the Green-Ampt infiltration model with shallow boundary conditions. Hydrol Eng 16(3):266-273

Loat R, Petrascheck A (1997) Prise en compte des dangers dus aux crues dans le cadre des activités de l'aménagement du territoire, Recommandations, Office fédéral de l'économie des eaux (OFEE), Office fédéral de l'aménagement du territoire (OFAT), Office fédéral de l'environnement, des forêts et du paysage (OFEFP), Berne

Lüthi R (2004) Cadre juridique des cartes de danger. Série PLANAT 5, Office fédéral des eaux et de la géologie, Bienne

Mahbub I, Monzur AI (2009) Improved continuing losses estimation using initial loss-continuing loss model for medium sized rural catchments. Am J Eng Appl Sci 2(4):796-803

McBratney AB, Mendonça Santos ML, Mynasny B (2003) On digital soil mapping. Geoderma 117:3-52

McKenzie NJ, Ryan PJ (1999) Spatial prediction of soil properties using environmental correlation. Geoderma 89:67-94

Morris MD (1991) Factorial sampling plans for preliminary computational experiments. Technometrics 2:161-174

Nikolopoulos EI, Anagnostou EN, Hossain F, Gebremichael M, Borga M (2010) Understanding the scale relationships of uncertainty propagation of satellite rainfall through a distributed hydrologic model. J Hydrometeorol 2:520-532

Nikolopoulos EI, Anagnostou EN, Borga M (2013) Using high-resolution satellite rainfall products to simulate a major flash flood event in Northern Italy. J Hydrometeorol 14:171-185

NRC (1996) Alluvial fan flooding. National Research Council, Committee on Alluvial Fan Flooding, National Academy Press, Washington DC 
NRCS (2007) Part 630 Hydrology. National engineering handbook. National Resources Conservation Service, Washington DC

Osterkampl WR, Friedman JM (2000) The disparity between extreme rainfall events and rare floods-with emphasis on the semi-arid American West. Hydrol Process 14:2817-2829

Pelletier JD, Pearthree PA, House PK, Demsey KA, Klawon JE, Vincent KR (2005) An integrated approach to flood hazard assessment on alluvial fans using numerical modelling, field mapping, and remote sensing. Geol Soc Am Bull 117(9-10):1167-1180

Penelas M, Delaloye R, November V, Reynard E, Ruegg J (2008) Cartes de dangers et aménagement du territoire, Thematic report. Action COST C19 «Impact des inondations en Suisse: processus d'apprentissage, gestion du risque et aménagement du territoire », Université de Lausanne, Université de Fribourg, Université de Zürich, Ecole polytechnique fédérale de Lausanne, Lausanne

Pilgrim DH, Chapman TG, Doran DG (1988) Problems of rainfall-runoff modelling in arid and semiarid regions. Hydrol Sci J 33(4):379-400

Reynard E, Werren G, Lasri M, Obda K, El Khalki Y (2013) Cartes des phénomènes d'inondation dans deux bassins versants marocains : problèmes méthodologiques. Mém. Soc. vaud. Sc. nat. 25:71-81

Saïdi ME, Daoudi L, Aresmouk ME, Fniguire F, Boukrim S (2010) Les crues de l'oued Ourika (Haut Atlas, Maroc): Événements extrêmes en contexte montagnard semi-aride. Comunicações Geológicas 97:113-128

Smagorinsky J (1963) General circulation experiments with the primitive equations. Mon Weather Rev 91:99-164

Smith RE, Eggert KG, Hawkins RM (1978) Discussion. Infiltration formula based on SCS curve number. J Irrig Drain Div Am Soc Civil Eng 104(IR4):462-467

Snyder FF (1938) Synthetic unit graphs. Trans Am Geophys Union 19:447-454

Su F, Hong Y, Lettenmaier DP (2008) Evaluation of TRMM multisatellite precipitation analysis (TMPA) and its utility in hydrologic prediction in the La Plata basin. J Hydrometeorol 9:622-640

Syme WJ (2001) TUFLOW-Two \& one-dimensional unsteady FLOW software for rivers, estuaries and coastal waters, IEAust water panel seminar and workshop on 2D flood modelling, Sydney, February 2001, http://www.tuflow.com/download/publications, Accessed 24 Aug 2012

Syme WJ, Apelt CJ (1990) Linked two-dimensional/one-dimensional flow modelling using the shallow water equations. The institution of engineers Australia. Conference on hydraulics in civil engineering 1990. Sydney, 3-5 July 1990:28-32

Tayefi V, Lane SN, Hardy RJ, Yu D (2007) A comparison of one- and two-dimensional approaches to modelling flood inundation over complex upland floodplains. Hydrol Process 21:3190-3202

Tramblay Y, Bouaicha R, Brocco L, Dorigo W, Bouvier C, Camici S, Servat E (2012) Estimation of antecedent wetness conditions for flood modelling in northern Morocco. Hydrol Earth Syst Sci $16: 4375-4386$

UNDP (2006) Programme de réduction des risques de catastrophes au Maroc. United Nations Development Program, New York

USACE (2000) Hydrologic modeling system HEC-HMS. Technical reference manual. US Army Corps of Engineers, Hydrologic Engineering Center, Davis

USACE (2010) HEC-RAS river analysis system. Hydraulic reference manual. U.S. Army Corps of Engineers, www.hec.usace.army/mil. Accessed 10 June 2010

Vincent KR, Pearthree PA, House PK, Demsey KA (2004) Inundation mapping and hydraulic reconstructions of an extreme alluvial fan flood, Wild Burro Wash, Pima County, southern Arizona. Arizona Geological Survey

WBM Oceanics Australia (2007) TUFLOW (and ESTRY) user manual. GIS-based 1D/2D hydrodynamic modelling. www.tuflow.com/downloads. Accessed 20 June 2012

Werren G (2013) Maps as risk mitigation tools. Adaptation of the Swiss hazard assessment and mapping methodology to a Moroccan site: Beni Mellal. Dissertation, University of Lausanne. http://my.unil.ch/ serval/document/BIB_28316A5BCD24.pdf

Yaalon DH (1997) Soils in the Mediterranean region: what makes them different? Catena 28:157-169

Yong B, Hong Y, Ren LL, Gourley JJ, Huffman GJ, Chen X, Wang W, Khan SI (2012) Assessment of evolving TRMM-based multisatellite real-time precipitation estimation methods and their impacts on hydrologic prediction in a high latitude basin. J Geophys Res. doi:10.1029/2011JD017069

Yu D, Lane SN (2006) Urban fluvial flood modelling using a two-dimensional diffusion-wave treatment, part 1: mesh resolution effects. Hydrol Process 20:1541-1565 